\title{
Preliminary validation of column-averaged volume mixing ratios of carbon dioxide and methane retrieved from GOSAT short-wavelength infrared spectra
}

\author{
I. Morino ${ }^{1}$, O. Uchino ${ }^{1}$, M. Inoue ${ }^{1}$, Y. Yoshida ${ }^{1}$, T. Yokota ${ }^{1}$, P. O. Wennberg ${ }^{2}$, G. C. Toon ${ }^{3}$, D. Wunch ${ }^{2}$, C. M. RoehI ${ }^{2}$, \\ J. Notholt ${ }^{4}$, T. Warneke ${ }^{4}$, J. Messerschmidt ${ }^{4}$, D. W. T. Griffith ${ }^{5}$, N. M. Deutscher ${ }^{5}$, V. Sherlock ${ }^{6}$, B. Connor ${ }^{6}$, \\ J. Robinson ${ }^{6}$, R. Sussmann ${ }^{7}$, and M. Rettinger ${ }^{7}$ \\ ${ }^{1}$ National Institute for Environmental Studies, 16-2 Onogawa, Tsukuba, Ibaraki 305-8506, Japan \\ ${ }^{2}$ California Institute of Technology, Pasadena, CA, 91125-2100, USA \\ ${ }^{3}$ Jet Propulsion Laboratory, California Institute of Technology, 4800 Oak Grove Drive, Pasadena, CA, 91109-8099, USA \\ ${ }^{4}$ Institute of Environmental Physics, University of Bremen, 28334 Bremen, Germany \\ ${ }^{5}$ Center for Atmospheric Chemistry, University of Wollongong, New South Wales 2522, Australia \\ ${ }^{6}$ National Institute of Water and Atmospheric Research, Wellington, New Zealand \\ ${ }^{7}$ IMK-IFU, Karlsruhe Institute of Technology, Garmisch-Partenkirchen, Germany
}

Received: 26 November 2010 - Published in Atmos. Meas. Tech. Discuss.: 8 December 2010

Revised: 25 April 2011 - Accepted: 19 May 2011 - Published: 15 June 2011

\begin{abstract}
Column-averaged volume mixing ratios of carbon dioxide and methane retrieved from the Greenhouse gases Observing SATellite (GOSAT) Short-Wavelength InfraRed observation (GOSAT SWIR $X_{\mathrm{CO}_{2}}$ and $X_{\mathrm{CH}_{4}}$ ) were compared with the reference calibrated data obtained by ground-based high-resolution Fourier Transform Spectrometers (g-b FTSs) participating in the Total Carbon Column Observing Network (TCCON).

Preliminary results are as follows: the GOSAT SWIR $X_{\mathrm{CO}_{2}}$ and $X_{\mathrm{CH}_{4}}$ (Version 01.xx) are biased low by 8.85 $\pm 4.75 \mathrm{ppm}(2.3 \pm 1.2 \%)$ and $20.4 \pm 18.9 \mathrm{ppb}(1.2 \pm 1.1 \%)$, respectively. The standard deviation of the GOSAT SWIR $X_{\mathrm{CO}_{2}}$ and $X_{\mathrm{CH}_{4}}$ is about $1 \%(1 \sigma)$ after correcting the negative biases of $X_{\mathrm{CO}_{2}}$ and $X_{\mathrm{CH}_{4}}$ by $8.85 \mathrm{ppm}$ and $20.4 \mathrm{ppb}$, respectively. The latitudinal distributions of zonal means of the GOSAT SWIR $X_{\mathrm{CO}_{2}}$ and $X_{\mathrm{CH}_{4}}$ show similar features to those of the g-b FTS data except for the negative biases in the GOSAT data.
\end{abstract}

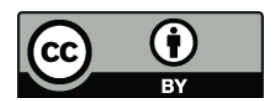

Correspondence to: O. Uchino (uchino.osamu@nies.go.jp)

\section{Introduction}

The concentration of carbon dioxide $\left(\mathrm{CO}_{2}\right)$ has increased from about 280 to $380 \mathrm{ppm}$ over the past century due to the burning of fossil fuels associated with expanding industrial activities (IPCC, 2007). $\mathrm{CO}_{2}$ absorbs infrared radiation from the surface and hence an increase in $\mathrm{CO}_{2}$ concentrations leads to a rise in atmospheric temperature. $\mathrm{CO}_{2}$ and other trace gases such as methane $\left(\mathrm{CH}_{4}\right)$, nitrous oxide $\left(\mathrm{N}_{2} \mathrm{O}\right)$, hydrofluorocarbons (HFCs), perfluorocarbons (PFCs) and sulfur hexafluoride $\left(\mathrm{SF}_{6}\right)$ are greenhouse gases that are subject to emissions regulations under the Kyoto Protocol. Together, $\mathrm{CO}_{2}$ and $\mathrm{CH}_{4}$ account for over 80 percent of the total anthropogenic warming effect caused by all greenhouse gases based on the estimates of radiative forcing from 1750 to 2005 (IPCC, 2007). Changes in temperature can cause feedbacks that alter $\mathrm{CO}_{2}$ concentrations by influencing the biosphere (Cox et al., 2000). Methane in the atmosphere is determined by a balance between emission from the surface and loss in the soils and by $\mathrm{OH}$ radicals in the atmosphere. After almost a decade of near-zero growth, globally-averaged atmospheric methane increased during 2007 and 2008. The cause of this increase is not yet clear (Dlugokencky et al., 2009). To accurately predict future atmospheric $\mathrm{CO}_{2}$ and $\mathrm{CH}_{4}$ concentrations and their impacts on climate, it is necessary to clarify the distribution and variations of those sources and sinks.

Published by Copernicus Publications on behalf of the European Geosciences Union. 
Current estimates of $\mathrm{CO}_{2}$ flux from inverse methods rely mainly on ground-based data (Baker et al., 2006). Errors in the estimation of regional fluxes from Africa and South America are particularly large because ground-based monitoring stations are sparsely located in those regions. Spectroscopic remote sensing from space is capable of acquiring data that cover the globe and hence is expected to reduce errors in the $\mathrm{CO}_{2}$ flux estimation using inverse modeling. To improve annual flux estimates on a sub-continental scale, the required precision of monthly averaged column-averaged volume mixing ratio of carbon dioxide $\left(X_{\mathrm{CO}_{2}}\right)$ is less than $1 \%$ on a $8^{\circ} \times 10^{\circ}$ grid without biases or with uniform biases (Rayner and O’Brien, 2001; Houweling et al., 2004; Miller et al., 2007). To reduce the uncertainty in monthly, subcontinental (about $500 \mathrm{~km}$ ) methane source strengths from satellite measurements, the precision of the column-averaged volume mixing ratios of methane is required to be 1-2\% without systematic biases (Meirink et al., 2006). For this purpose, satellite-based data products must be validated by higher-precision data obtained independently using groundbased or aircraft measurements (Chahine et al., 2005; Sussmann et al., 2005; Dils et al., 2006; Schneising et al., 2008; Kulawik et al., 2010).

In this study, data products retrieved by the National Institute for Environmental Studies (NIES) from spectra obtained by the Greenhouse gases Observing SATellite (GOSAT) are compared with ground-based high-resolution Fourier Transform Spectrometer ( $\mathrm{g}$-b FTS) data calibrated to the World Meteorological Organization (WMO) scale. In Sect. 2, we present an overview of the GOSAT project, GOSAT instruments and observations, and retrievals from the GOSAT Thermal And Near-infrared Sensor for carbon Observation Fourier Transform Spectrometer, measuring in the ShortWavelength InfraRed (TANSO-FTS SWIR). Reference data measured with g-b FTS are described in Sect. 3. Characteristics of GOSAT SWIR products and preliminary results compared with the reference data are presented in Sect. 4, and the discussion and conclusions follow.

\section{Overview of GOSAT, the GOSAT instruments, and data products retrieved from GOSAT TANSO-FTS SWIR observations}

\subsection{GOSAT}

GOSAT, launched on 23 January 2009, is the world's first satellite dedicated to measuring the atmospheric concentrations of $\mathrm{CO}_{2}$ and $\mathrm{CH}_{4}$ from space. The GOSAT Project is a joint effort of the Ministry of the Environment (MOE), the NIES, and the Japan Aerospace Exploration Agency (JAXA). NIES is responsible for (1) developing the retrieval of greenhouse gas concentrations (Level 2 products) from satellite and auxiliary data, (2) validating the retrieved greenhouse gas concentrations, and (3) producing higher-level processing such as monthly averaged $X_{\mathrm{CO}_{2}}$ and $X_{\mathrm{CH}_{4}}$ (Level 3 products) and Level 4 carbon flux estimates. The primary purpose of the GOSAT is to make more accurate estimates of these fluxes on sub-continental scales (several hundred thousand square kilometers) and contributing toward the broader effort of environmental monitoring of ecosystem carbon balance. Further, through research using the GOSAT product, new knowledge will be accumulated on the global distribution of greenhouse gases and their temporal variations, as well as the global carbon cycle and its influence on climate. These new findings will be utilized to improve predictions of future climate change and its impacts.

\subsection{GOSAT instruments and observation methods}

Details of the GOSAT instruments have been described by Kuze et al. (2009). GOSAT is placed in a sun-synchronous orbit with an equator crossing time of about 13:00 local time, with an inclination angle of 98 degrees. GOSAT flies at an altitude of approximately $666 \mathrm{~km}$ and completes an orbit in about $100 \mathrm{~min}$. The spacecraft returns to observe the same point on Earth every three days. The instruments onboard the satellite are TANSO-FTS and the TANSO Cloud and Aerosol Imager (TANSO-CAI).

TANSO-FTS has a Michelson interferometer that was custom designed and built by ABB-Bomem, Quebec, Canada. Spectra are obtained in four bands: band 1 spanning 0.758 $0.775 \mu \mathrm{m}\left(12900-13200 \mathrm{~cm}^{-1}\right)$ with $0.37 \mathrm{~cm}^{-1}$ or better spectral resolution, and bands 2-4, spanning 1.56-1.72, 1.92-2.08, and 5.56-14.3 $\mu \mathrm{m}(5800-6400,4800-5200$, and $700-1800 \mathrm{~cm}^{-1}$, respectively) with $0.26 \mathrm{~cm}^{-1}$ or better spectral resolution. The TANSO-FTS instantaneous field of view is $\sim 15.8 \mathrm{mrad}$ corresponding to a nadir footprint diameter of about $10.5 \mathrm{~km}$ at sea level. The nominal single-scan data acquisition time is $4 \mathrm{~s}$.

TANSO-FTS observes solar light reflected from the earth's surface as well as the thermal radiance emitted from the atmosphere and the surface. The former (SWIR region) is observed in bands 1 to 3 of the FTS in the daytime only, and the latter (Thermal InfraRed, TIR, region) is captured in band 4 during both the day and the night. The surface reflection characteristics of land and water differ significantly. The land is close to Lambertian, whereas the ocean is much more specular. TANSO-FTS observes scattered sunlight over land using a nadir-viewing observation mode, and over ocean using a sunglint observation mode.

TANSO-CAI is a radiometer and observes the state of the atmosphere and the surface during daytime. The image data from CAI are used to determine cloud properties over an extended area that includes the FTS' field of view as described by Ishida and Nakajima (2009). As part of the retrieval, cloud characteristics and aerosol amounts are also retrieved. This information can be used to reject cloudy scenes and correct the influence of aerosols on the retrieved $X_{\mathrm{CO}_{2}}$ and $X_{\mathrm{CH}_{4}}$. 
Over the three-day orbital repeat period, TANSO-FTS takes several tens of thousands of observations that cover the globe. Since the retrievals are limited to areas under clear sky conditions, only about ten percent of the spectra obtained by TANSO-FTS can be used for the retrieval of $\mathrm{CO}_{2}$ and $\mathrm{CH}_{4}$. Nevertheless, the number of remaining data points far surpasses the current number of ground monitoring stations used for analysis in the World Data Centre for Greenhouse Gases (WDCGG), which is below 200 (WMO, 2009). GOSAT serves to fill in the blanks in the ground observation network.

\subsection{Products retrieved from GOSAT TANSO-FTS SWIR spectra}

The analysis of the TANSO-FTS SWIR spectra is described in detail by Yoshida et al. (2011). Briefly, absorption spectra at bands 1 and 2 are used together to retrieve $\mathrm{CO}_{2}$ and $\mathrm{CH}_{4}$ column abundances. From all spectra observed with TANSO-FTS SWIR, only those measured without cloud interference are selected for further processing. Based on the absorption characteristics of each gas, the selected spectra are used to retrieve column abundances of $\mathrm{CO}_{2}$ and $\mathrm{CH}_{4}$ (Level 2 product). The retrieval errors of $X_{\mathrm{CO}_{2}}$ and $X_{\mathrm{CH}_{4}}$ are on average $2 \mathrm{ppm}$ and $8 \mathrm{ppb}$ or about $0.5 \%$ respectively. The retrieval errors include TANSO-FTS SWIR measurement noise, smoothing error and interference error, and the main error is the measurement noise (Yoshida et al., 2011). Variations in the $\mathrm{CO}_{2}$ concentration are most obvious near the surface of the earth. The $\mathrm{CO}_{2}$ absorption bands near $1.6 \mu \mathrm{m}$ and $2.0 \mu \mathrm{m}$ provide information on the near-surface concentrations. On the other hand, the TIR absorption band around $14 \mu \mathrm{m}$ is used to obtain information on the profiles of $\mathrm{CO}_{2}$ and $\mathrm{CH}_{4}$, mainly at altitudes above $2 \mathrm{~km}$ (Saitoh et al., 2009). The retrievals from the TIR spectra and the validation of their products will be presented in a forthcoming paper.

Validation of the TANSO-FTS SWIR Level 2 data product is critical since the data are used for generating Level 3 and Level 4 products. GOSAT Level 2 products are evaluated against high-precision data obtained independently using ground-based or aircraft observations. Here we compare the GOSAT SWIR $X_{\mathrm{CO}_{2}}$ and $X_{\mathrm{CH}_{4}}$ results with those data obtained with ground-based high-resolution FTSs (g-b FTSs).

\section{Reference data for GOSAT product validation}

Spectra measured with g-b FTS are analyzed using the GFIT nonlinear least squares spectral fitting algorithm developed at the Jet Propulsion Laboratory (Toon et al., 1992; Wunch et al., 2011), which is used for retrievals across all stations that comprise the Total Carbon Column Observing Network (TCCON; Wunch et al., 2011). Here, we use the GFIT 7 Mar 2009 release.
The column-averaged volume mixing ratio of $\mathrm{CO}_{2}\left(X_{\mathrm{CO}_{2}}\right)$ or $\mathrm{CH}_{4}\left(\mathrm{X}_{\mathrm{CH}_{4}}\right)$ is defined to be the ratio of the $\mathrm{CO}_{2}\left(\right.$ or $\left.\mathrm{CH}_{4}\right)$ column amount to the dry air column amount. To calculate the dry air column, the GFIT software uses the measured $\mathrm{O}_{2}$ column, divided by the known dry air mole fraction of $\mathrm{O}_{2}$ (0.2095). The $\mathrm{O}_{2}$ column is measured simultaneously with the $\mathrm{CO}_{2}$ and $\mathrm{CH}_{4}$ columns using the spectral band covering 1.25-1.29 $\mu \mathrm{m} . X_{\mathrm{CO}_{2}}$ and $X_{\mathrm{CH}_{4}}$ are then obtained from:

$X_{\mathrm{CO}_{2}}=0.2095\left(\mathrm{CO}_{2}\right.$ column $/ \mathrm{O}_{2}$ column $)$

$X_{\mathrm{CH}_{4}}=0.2095\left(\mathrm{CH}_{4}\right.$ column $/ \mathrm{O}_{2}$ column $)$

Ratioing by $\mathrm{O}_{2}$ minimizes systematic and correlated errors present in both retrieved columns like pointing error, surface pressure uncertainty, instrument line shape uncertainty, $\mathrm{H}_{2} \mathrm{O}$ vapor uncertainty, zero level offsets and solar intensity variation (e.g. thin clouds). We use "uncertainty" as

uncertainty $^{2}=$ accuracy $^{2}+$ precision $^{2}$

accuracy $=$ bias $=$ systematic error

precision $=$ random error .

The precision of $\mathrm{g}$-b FTS measurement of $X_{\mathrm{CO}_{2}}$ is better than $0.2 \%$ under clear sky conditions (Washenfelder et al., 2006; Ohyama et al., 2009; Wunch et al., 2011; Messerschmidt et al., 2010). All TCCON $X_{\mathrm{CO}_{2}}$ data are corrected for an airmass-dependent artifact (Wunch et al., 2011). Aircraft profiles obtained over many of these sites are used to determine an empirical scaling to place the TCCON data on the WMO standard reference scale. The scaling factors of $X_{\mathrm{CO}_{2}}$ and $X_{\mathrm{CH}_{4}}$ are 1.011 and 1.022, respectively. The uncertainty of $X_{\mathrm{CO}_{2}}$ and $X_{\mathrm{CH}_{4}}$ associated with the g-b FTS measurement is estimated to be $0.8 \mathrm{ppm}(\sim 0.2 \%)$ and $4 \mathrm{ppb}(\sim 0.2 \%)$ by comparing the TCCON retrievals with many different aircraft profiles (Wunch et al., 2010).

The g-b FTS data at nine TCCON sites are used in this analysis. Figure 1 shows the location of the FTS sites which are used in the present study. FTS sites are located in Asia, Oceania, Europe, and North America. Table 1 summarizes the spatial coordinates of those stations.

\section{Results of initial validation}

\subsection{GOSAT product selection for validation}

The GOSAT SWIR $X_{\mathrm{CO}_{2}}$ and $X_{\mathrm{CH}_{4}}$ products used here are Ver.01.xx. The retrieval algorithm for Ver.01.xx uses band 1 $\left(12900-13200 \mathrm{~cm}^{-1}\right)$ and band $2\left(5800-6400 \mathrm{~cm}^{-1}\right)$ to simultaneously estimate $X_{\mathrm{CO}_{2}}$ and $X_{\mathrm{CH}_{4}}$. In addition, the water vapor column and aerosol optical depth (AOD) at a wavelength of $1.6 \mu \mathrm{m}$ are retrieved. Band 3 is used for selecting scenes with cirrus clouds which CAI can not detect (Yoshida et al., 2011). Table 2 summarizes the spectral line parameters of $\mathrm{CO}_{2}, \mathrm{CH}_{4}, \mathrm{H}_{2} \mathrm{O}$ and $\mathrm{O}_{2}$ molecules and the parameters 
Table 1. Ground-based FTS sites used for GOSAT product validation.

\begin{tabular}{lllll}
\hline Site & Country & Coordinate [Lat., Long.] & Alt. [m a.s.l.] & Reference \\
\hline Bialystok & Poland & $53.23^{\circ} \mathrm{N}, 23.0253^{\circ} \mathrm{E}$ & 180 & Messerschmidt et al. (2010) \\
Orléans & France & $47.965^{\circ} \mathrm{N}, 2.11253^{\circ} \mathrm{E}$ & 130 & Messerschmidt et al. (2010) \\
Garmisch & Germany & $47.476^{\circ} \mathrm{N}, 11.0633^{\circ} \mathrm{E}$ & 746.6 & Sussmann et al. (2009) \\
Park Falls & USA & $45.945^{\circ} \mathrm{N}, 90.2733^{\circ} \mathrm{W}$ & 442 & Washenfelder et al. (2006) \\
Lamont & USA & $36.604^{\circ} \mathrm{N}, 97.4863^{\circ} \mathrm{W}$ & 320 & Wunch et al. (2010, 2011) \\
Tsukuba & Japan & $36.0513^{\circ} \mathrm{N}, 140.12153^{\circ} \mathrm{E}$ & 31 & Ohyama et al. (2009) \\
Darwin & Australia & $12.424453^{\circ} \mathrm{S}, 130.891543^{\circ} \mathrm{E}$ & 32 & Deutscher et al. (2010) \\
Wollongong & Australia & $34.40633^{\circ} \mathrm{S}, 150.8793^{\circ} \mathrm{E}$ & 30 & \\
Lauder & New Zealand & $45.03843^{\circ} \mathrm{S}, 169.6843^{\circ} \mathrm{E}$ & 370 & \\
\hline
\end{tabular}

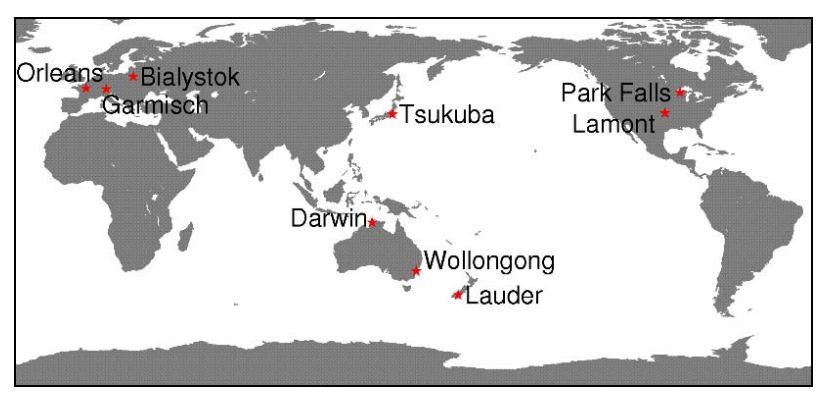

Fig. 1. Ground-based FTS sites used for the GOSAT product validation in the present study.

retrieved from bands 1 and 2 of TANSO-FTS. The grid point values of the meteorological data analyzed by the Japan Meteorological Agency are interpolated to the retrieval points. The $X_{\mathrm{CO}_{2}}$ and $X_{\mathrm{CH}_{4}}$ data shown here (general public users, or GU subset) are filtered for AOD less than 0.5. As a planeparallel atmosphere is assumed in the retrieval, data with solar zenith angles greater than 70 degrees are not processed, and data over high mountain ranges such as the Rockies, the Andes, and the Himalayan mountains are removed.

\subsection{Global distribution of $X_{\mathrm{CO}_{2}}$ and $X_{\mathrm{CH}_{4}}$}

Figures 2 and 3 show the global distribution of the monthlyaveraged GOSAT SWIR $X_{\mathrm{CO}_{2}}$ and $X_{\mathrm{CH}_{4}}$ data, gridded in $1.5^{\circ}$ by $1.5^{\circ}$ bins in April and October 2009, respectively. These retrievals satisfy the filter criteria over North Africa, the Arabian Peninsula, and Australia. Data over land are obtained mainly for $10-60^{\circ} \mathrm{N}$ and $15-45^{\circ} \mathrm{S}$ in April, and 10$50^{\circ} \mathrm{N}$ and $0-50^{\circ} \mathrm{S}$ in October. Data over ocean are retrieved in the regions of $10^{\circ} \mathrm{S}-30^{\circ} \mathrm{N}$ in April and $40^{\circ} \mathrm{S}-10^{\circ} \mathrm{N}$ in October by observing the specular reflection of sunlight in the direction of sunglint.

$X_{\mathrm{CO}_{2}}$ in April is generally higher in the Northern Hemisphere than the Southern Hemisphere (Fig. 2). This is because plant photosynthesis in the Northern Hemisphere is not yet competitive with respiration in April. In October, similar
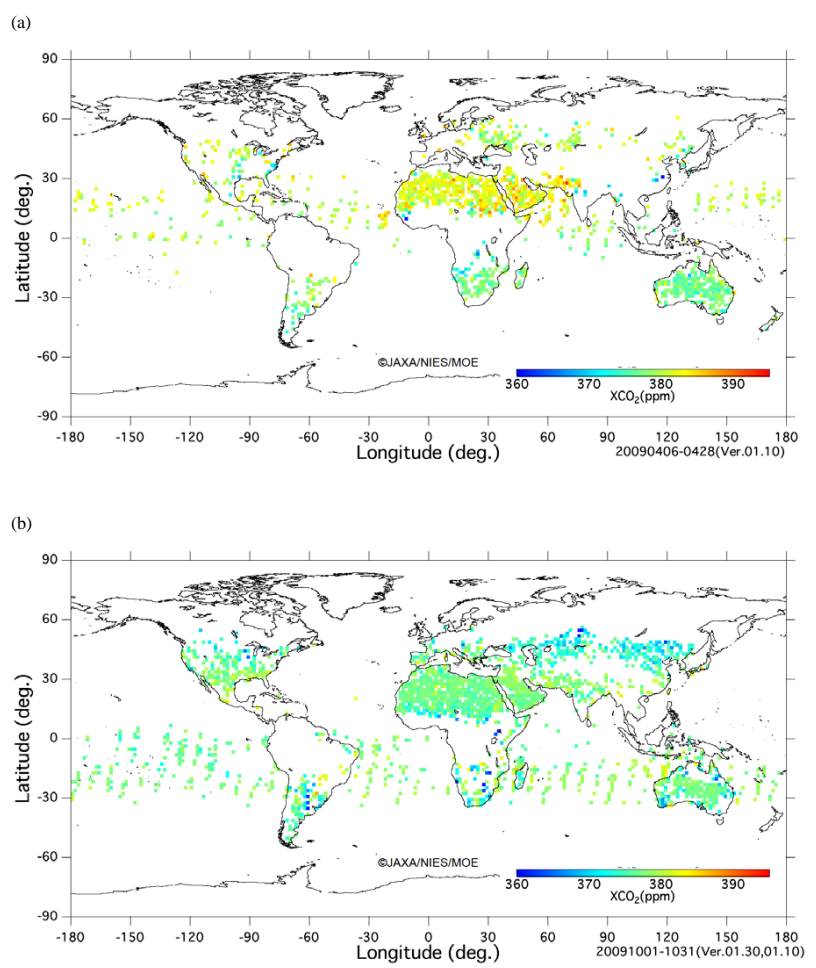

Fig. 2. Global distribution of GOSAT SWIR $X_{\mathrm{CO}_{2}}$ averaged monthly in 1.5 by 1.5 degree bins for (a) April and (b) October in 2009.

$X_{\mathrm{CO}_{2}}$ is observed in both hemispheres. The standard deviations of monthly mean $X_{\mathrm{CO}_{2}}$ is about $1 \%$ for a $10^{\circ} \times 10^{\circ}$ grid over Australia, where gradients are anticipated to be very small.

$X_{\mathrm{CH}_{4}}$ in the Northern Hemisphere is higher than in the Southern Hemisphere in both April and October 2009 (Fig. 3). Elevated $X_{\mathrm{CH}_{4}}$ is observed from India to Japan in October 2009. These features are similar to those obtained by SCIAMACHY (Frankenberg et al., 2006) and simulated by an inversion model (Bergamaschi et al., 2007). 
Table 2. (a) Spectroscopic databases of $\mathrm{CO}_{2}, \mathrm{CH}_{4}, \mathrm{H}_{2} \mathrm{O}$ and $\mathrm{O}_{2}$ molecules and (b) parameters retrieved from bands 1 and 2 of the TANSO FTS in the Ver.01.xx.

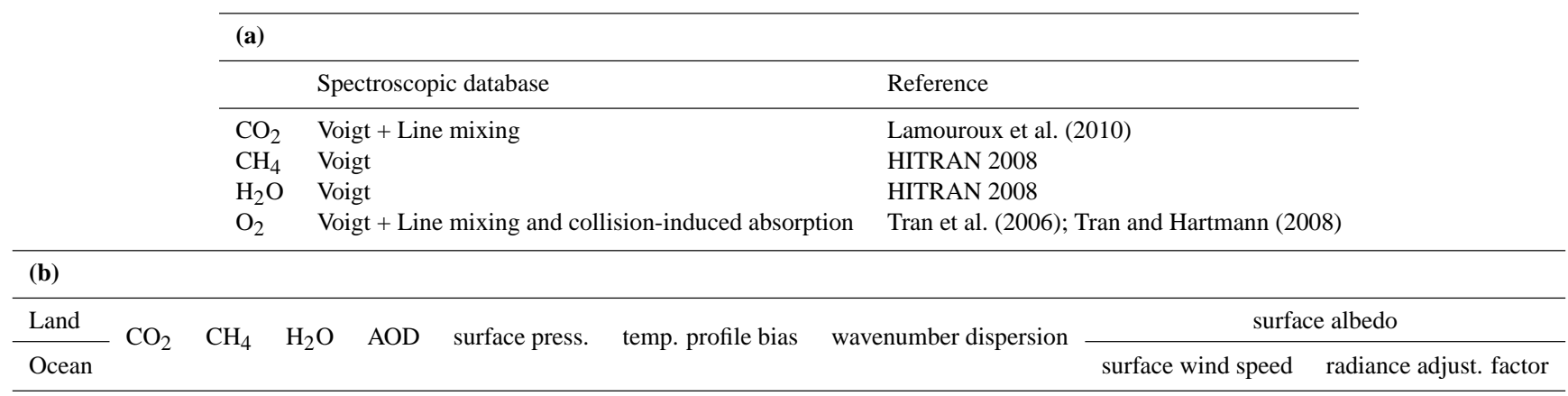
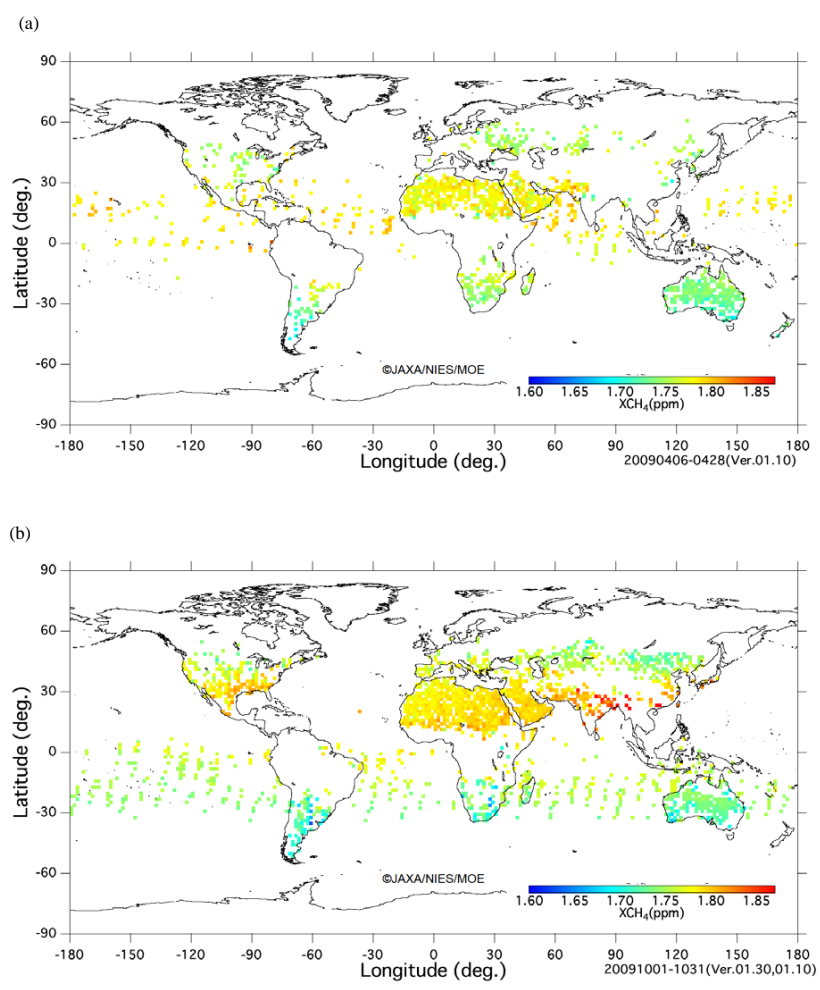

Fig. 3. Global distribution of GOSAT SWIR $X_{\mathrm{CH}_{4}}$ averaged monthly in 1.5 by 1.5 degree bins for (a) April and (b) October in 2009 .

\subsection{Comparisons between g-b FTS data and GOSAT TANSO-FTS SWIR data}

GOSAT TANSO-FTS SWIR data are compared with the g-b FTS data at 9 TCCON sites (Fig. 1). We illustrate here the time series of the TANSO-FTS SWIR Level 2 data and g-b FTS data and their scatter diagrams for $X_{\mathrm{CO}_{2}}$ and $X_{\mathrm{CH}_{4}}$. The g-b FTS data are the mean values and standard deviations $(1 \sigma)$ measured at each FTS site within \pm 30 min of GOSAT overpass time (at most sites, around 13:00 local time). The
GOSAT data are selected within about 0.5 to 1.5 degrees rectangular area centered at each FTS site depending on the geographical distribution of land and sea. As much as possible, we used only the GOSAT data retrieved over flat land.

\subsection{1 $X_{\mathrm{CO}_{2}}$}

The time series of the GOSAT and g-b FTS data for $X_{\mathrm{CO}_{2}}$ are shown on the left and their scatter diagrams on the right in Fig. 4. In the scatter diagram, we plotted data when g-b FTS data were collected within $\pm 30 \mathrm{~min}$ of the GOSAT overpass time and corresponding GOSAT $X_{\mathrm{CO}_{2}}$ values were successfully retrieved. Therefore, the number of the GOSAT data in the scatter diagram is less than that in the time series. Only a few GOSAT data are available for comparison with Bialystok, Garmisch, Park Falls and Lauder. Darwin FTS data were not obtained from May 2010 through September 2010 due to mechanical problems with the sun tracker. $X_{\mathrm{CO}_{2}}$ retrieved from GOSAT SWIR measured near Orléans, Lamont and Tsukuba sites are higher in boreal spring and lower in autumn (Fig. 4b, e, and f). A clear seasonality over the Northern Hemisphere can also be seen in the maps in Fig. 2. In contrast, the seasonal variation of g-b FTS $X_{\mathrm{CO}_{2}}$ in the Southern Hemisphere (i.e., Darwin, Wollongong, and Lauder) is weak (Fig. 4g, h, and i) as expected due to smaller contribution of the continents.

Figure 5 shows the scatter diagram between the GOSAT data and the g-b FTS data for all sites, and the slope of the regression line with no intercept is 0.977 with a correlation coefficient of 0.378 and Table 3 summarizes the difference of the GOSAT data to the g-b FTS data at each site. The difference of the GOSAT data to the g-b FTS data is $-8.85 \pm 4.75 \mathrm{ppm}$ or $-2.3 \pm 1.2 \%$.

\subsection{2 $\quad X_{\mathrm{CH}_{4}}$}

The time series of the GOSAT and g-b FTS data for $X_{\mathrm{CH}_{4}}$ are shown on the left and their scatter diagrams on the right in Fig. 6. The bias of $X_{\mathrm{CH}_{4}}$ is smaller than that of $X_{\mathrm{CO}_{2}}$. 
Table 3. Left side: the average and one standard deviation $(1 \sigma)$ of the difference between GOSAT $X_{\mathrm{CO}_{2}}$ and g-b FTS $X_{\mathrm{CO}_{2}}$ for the nine TCCON sites. Right side: the average and one standard deviation $(1 \sigma)$ of the difference normalized to g-b FTS $X_{\mathrm{CO}_{2}}$ (given in percent). Note that the number of data listed here indicates the count of valid cases in which g-b FTS data were collected within \pm 30 min of the GOSAT overpass time and corresponding GOSAT $X_{\mathrm{CO}_{2}}$ values were successfully retrieved.

\begin{tabular}{l|rrr|cr}
\hline \multirow{2}{*}{ Sites } & $\begin{array}{r}\left.\text { (GOSAT SWIR } X_{\mathrm{CO}_{2}}\right)- \\
\left(\mathrm{g}-\mathrm{b} \text { FTS } X_{\mathrm{CO}_{2}}\right)\end{array}$ & $\begin{array}{c}{\left[\left(\mathrm{GOSAT} \mathrm{SWIR} X_{\mathrm{CO}_{2}}\right)-\right.} \\
\left.\left(\mathrm{g}-\mathrm{b} \text { FTS } X_{\mathrm{CO}_{2}}\right)\right] / \\
\left(\mathrm{g}-\mathrm{b} \text { FTS } X_{\mathrm{CO}_{2}}\right)\end{array}$ \\
\cline { 2 - 6 } & $\begin{array}{r}\text { Number } \\
\text { of data }\end{array}$ & $\begin{array}{r}\text { Average } \\
(\mathrm{ppm})\end{array}$ & $\begin{array}{r}1 \sigma \\
(\mathrm{ppm})\end{array}$ & $\begin{array}{c}\text { Average } \\
(\%)\end{array}$ & $\begin{array}{c}1 \sigma \\
(\%)\end{array}$ \\
\hline Bialystok & 1 & 5.01 & - & 1.32 & - \\
Orléans & 14 & -12.85 & 3.79 & -3.33 & 0.99 \\
Garmisch & 3 & -7.78 & 3.78 & -2.00 & 0.96 \\
Park Falls & 1 & -6.05 & - & -1.58 & - \\
Lamont & 11 & -10.31 & 4.80 & -2.65 & 1.23 \\
Tsukuba & 13 & -6.38 & 2.75 & -1.64 & 0.71 \\
Darwin & 6 & -6.09 & 2.61 & -1.58 & 0.68 \\
Wollongong & 11 & -8.77 & 4.74 & -2.28 & 1.23 \\
Lauder & 2 & -7.45 & 0.15 & -1.94 & 0.04 \\
\hline All data & 62 & -8.85 & 4.75 & -2.29 & 1.23 \\
\hline
\end{tabular}

Table 4. As in Table 3 except for $X_{\mathrm{CH}_{4}}$.

\begin{tabular}{l|rrr|cr}
\hline Sites & $\begin{array}{r}\left.\text { (GOSAT SWIR } X_{\mathrm{CH}_{4}}\right)- \\
\left(\mathrm{g}-\mathrm{b} \text { FTS } X_{\mathrm{CH}_{4}}\right)\end{array}$ & $\begin{array}{c}{\left[\left(\mathrm{GOSAT} \mathrm{SWIR} X_{\mathrm{CH}_{4}}\right)-\right.} \\
\left.\left(\mathrm{g}-\mathrm{b} \mathrm{FTS} X_{\mathrm{CH}_{4}}\right)\right] / \\
\left(\mathrm{g}-\mathrm{b} \mathrm{FTS} X_{\mathrm{CH}_{4}}\right)\end{array}$ \\
\cline { 2 - 6 } & $\begin{array}{r}\text { Number } \\
\text { of data }\end{array}$ & $\begin{array}{r}\text { Average } \\
(\mathrm{ppm})\end{array}$ & $\begin{array}{r}1 \sigma \\
(\mathrm{ppm})\end{array}$ & $\begin{array}{c}\text { Average } \\
(\%)\end{array}$ & $\begin{array}{r}1 \sigma \\
(\%)\end{array}$ \\
\hline Bialystok & 1 & 0.0227 & - & 1.29 & - \\
Orléans & 14 & -0.0367 & 0.0178 & -2.06 & 1.00 \\
Garmisch & 3 & -0.0114 & 0.0160 & -0.64 & 0.90 \\
Park Falls & 1 & -0.0120 & - & -0.66 & - \\
Lamont & 11 & -0.0230 & 0.0181 & -1.28 & 1.01 \\
Tsukuba & 13 & -0.0120 & 0.0115 & -0.67 & 0.64 \\
Darwin & 6 & -0.0080 & 0.0089 & -0.46 & 0.51 \\
Wollongong & 11 & -0.0235 & 0.0190 & -1.34 & 1.08 \\
Lauder & 2 & -0.0067 & 0.0003 & -0.39 & 0.01 \\
\hline All data & 62 & -0.0204 & 0.0189 & -1.15 & 1.06 \\
\hline
\end{tabular}

In Lamont and Orléans, $X_{\mathrm{CH}_{4}}$ levels obtained from GOSAT SWIR are higher in boreal autumn. The g-b FTS data of $X_{\mathrm{CH}_{4}}$ over Tsukuba have a peak in summer rather than autumn.

Figure 7 shows the scatter diagram between the GOSAT data and the g-b FTS data for all sites. The slope of the regression line with no intercept is 0.998 and the correlation coefficient is 0.681 . The difference between the GOSAT data and the g-b FTS data at each site is shown in Table 4. The difference of the GOSAT data to the g-b FTS data is $-20.4 \pm 18.9 \mathrm{ppb}$ or $-1.2 \pm 1.1 \%$. (a)

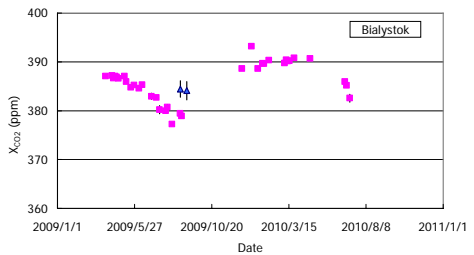

(b)

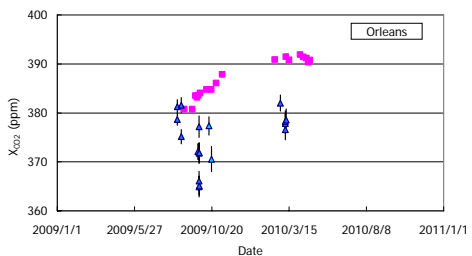

(c)

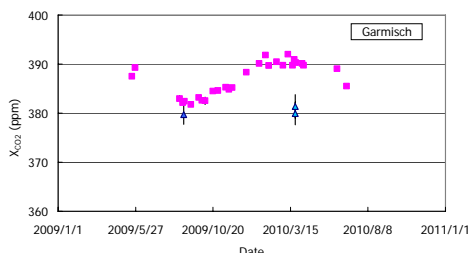

(d)
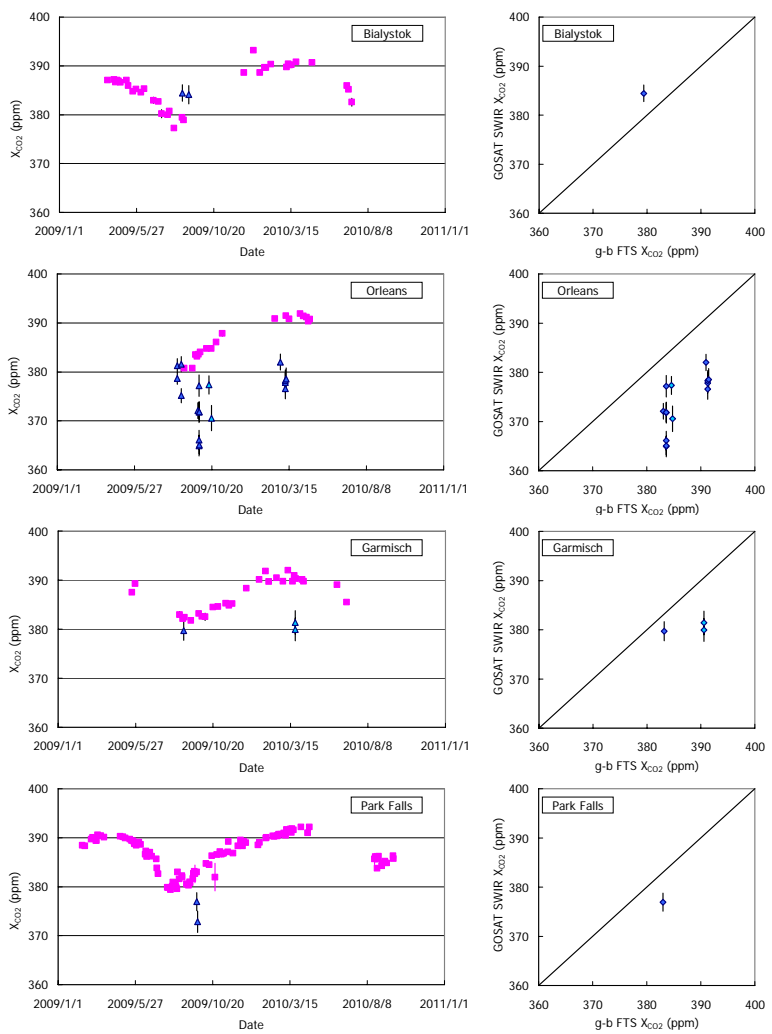

Fig. 4. Time series of GOSAT TANSO-FTS SWIR (blue triangles) and g-b FTS (pink squares) $X_{\mathrm{CO}_{2}}$ and their scatter diagrams for (a) Bialystok, (b) Orléans, (c) Garmisch, (d) Park Falls, (e) Lamont, (f) Tsukuba, (g) Darwin, (h) Wollongong, and (i) Lauder.

\subsubsection{Remarks and relaxed coincidence criteria}

There are too few data points in Tables 3 and 4 to compute meaningful statistics. For statistical significance, we have to consider all the data (62) in Tables 3 and 4. For Orléans, Lamont, Tsukuba and Wollongong, where there are more than 10 coincident data points in Table 3, site-dependent biases are the same within the mutual standard deviations. However, this is a topic for further investigation.

We relaxed the coincidence criteria. Comparison of the GOSAT data retrieved within \pm 2 and \pm 5 degrees latitude/longitude box centered at each g-b FTS site and the mean values of the g-b FTS data measured within $\pm 1 \mathrm{~h}$ of GOSAT overpass time can be found in Appendixes A and B. For \pm 2 degree latitude/longitude, the GOSAT $X_{\mathrm{CO}_{2}}$ and $X_{\mathrm{CH}_{4}}$ are biased low by $8.57 \pm 4.44 \mathrm{ppm}(2.2 \pm 1.2 \%)$ and $15.8 \pm 22.3 \mathrm{ppb}(0.89 \pm 1.26 \%)$, respectively. For \pm 5 degree latitude/longitude, the GOSAT $X_{\mathrm{CO}_{2}}$ and $X_{\mathrm{CH}_{4}}$ are biased low by $8.25 \pm 3.97 \mathrm{ppm}(2.1 \pm 1.0 \%)$ and $14.8 \pm 22.6 \mathrm{ppb}$ $(0.83 \pm 1.27 \%)$, respectively. These results are nearly equal to those in Tables 3 and 4 . For these relaxed coincidence criteria, site-dependent biases of the GOSAT $X_{\mathrm{CO}_{2}}$ and $X_{\mathrm{CH}_{4}}$ are also the same within the mutual standard deviations 
(e)

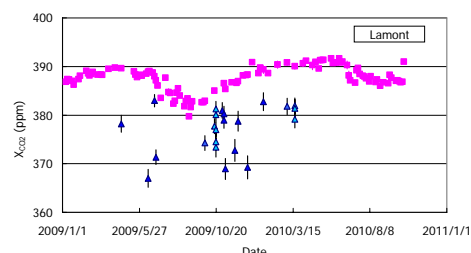

(f)

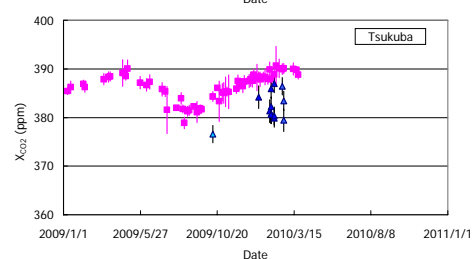

(g)

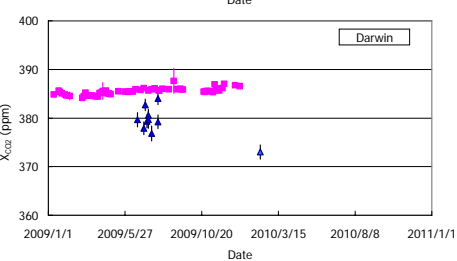

(h)

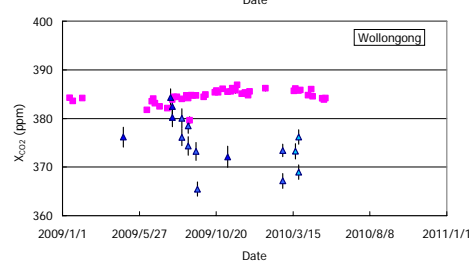

(i)

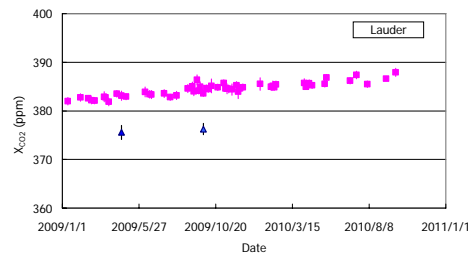

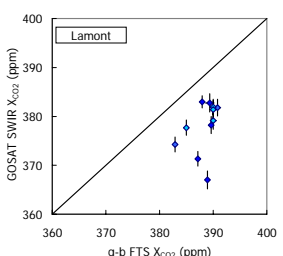
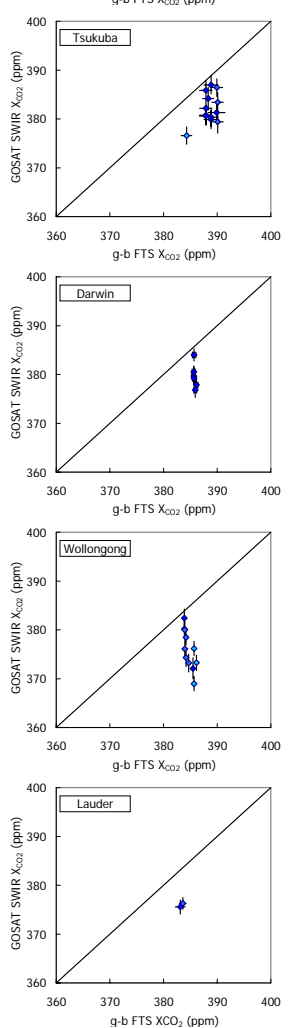

Fig. 4. Continued.

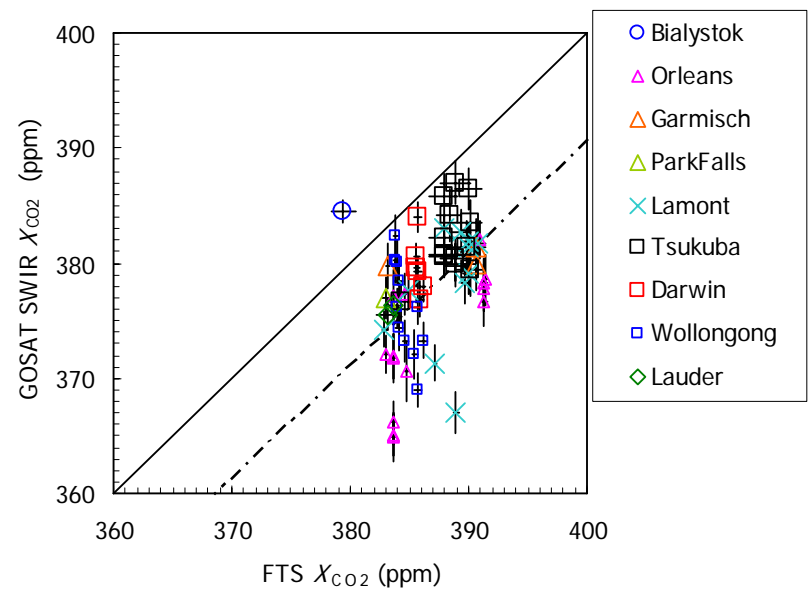

Fig. 5. Scatter diagram between GOSAT TANSO-FTS SWIR and g-b FTS $X_{\mathrm{CO}_{2}}$ at all FTS sites.

(a)

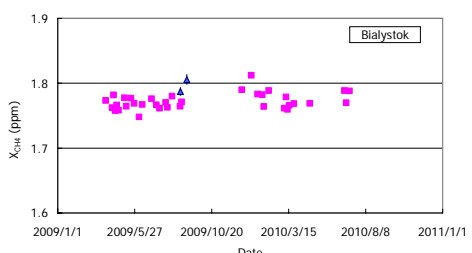

(b)

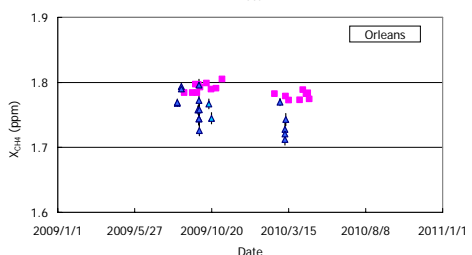

(c)

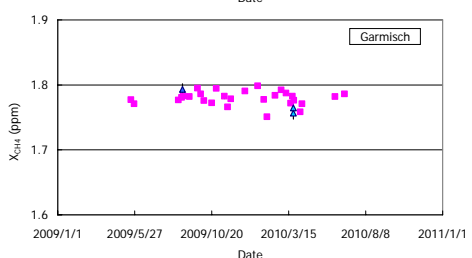

(d)

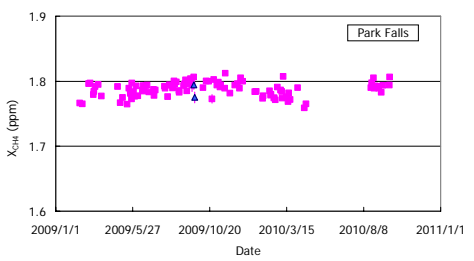

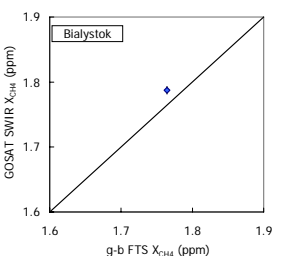
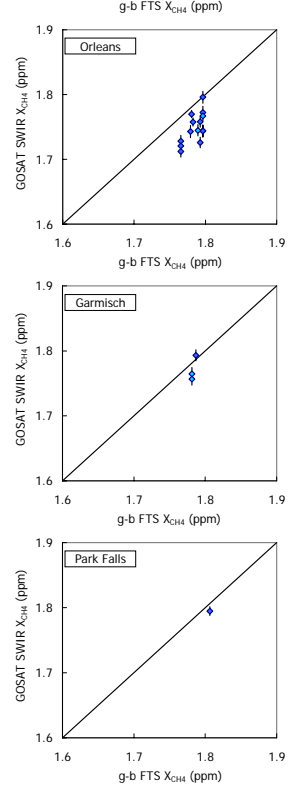

Fig. 6. Time series of GOSAT TANSO-FTS SWIR (blue triangles) and g-b FTS (pink squares) $X_{\mathrm{CH}_{4}}$ and their scatter diagrams for (a) Bialystok, (b) Orléans, (c) Garmisch, (d) Park Falls, (e) Lamont, (f) Tsukuba, (g) Darwin, (h) Wollongong, and (i) Lauder.

because the standard deviations of the biases are large at respective FTS sites. However, the peak-to-peak variation of the biases from site to site is now $1.2-1.8 \%$. We have to investigate further to decrease the variation of the biases.

\subsection{Latitudinal distributions of zonal averaged GOSAT SWIR $X_{\mathrm{CO}_{2}}$ and $X_{\mathrm{CH}_{4}}$}

In Sect. 4.3, g-b FTS data recorded within $\pm 30 \mathrm{~min}$ of the GOSAT overpass were used for the validation. To obtain larger numbers of samples and depict the latitudinal features, we calculated monthly mean $X_{\mathrm{CO}_{2}}$ and $X_{\mathrm{CH}_{4}}$ of g-b FTS data obtained within \pm 30 min of the time when GOSAT is supposed to overpass for all days, including the days when GOSAT does not overpass each site. In addition, monthly mean values of zonal averaged GOSAT data, based on all data obtained, are calculated in each 15 degree latitudinal band.

Latitudinal distributions of monthly means of zonal averaged GOSAT SWIR and g-b FTS data of $X_{\mathrm{CO}_{2}}$ in April and October 2009 are shown in Fig. 8. Both data sets show that $X_{\mathrm{CO}_{2}}$ is higher in the Northern Hemisphere compared with the Southern Hemisphere in April and the difference between 
(e)

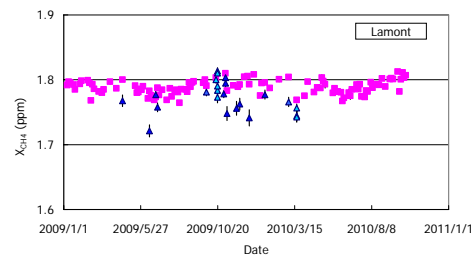

(f)

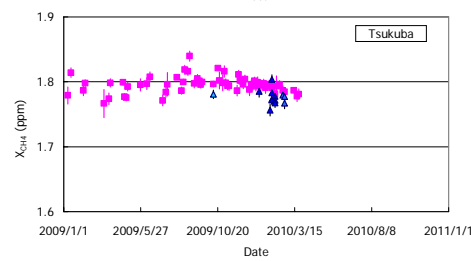

(g)

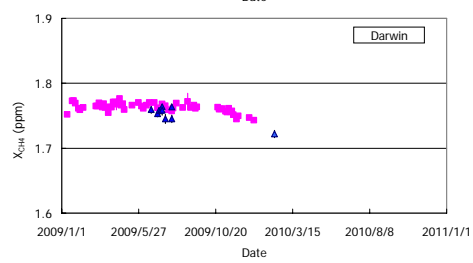

(h)

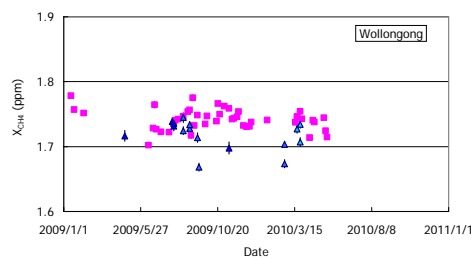

(i)

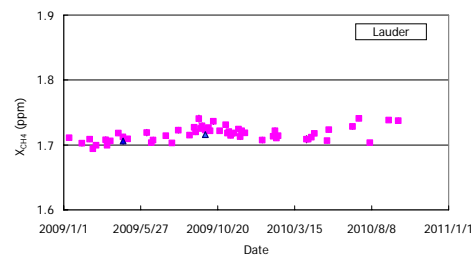

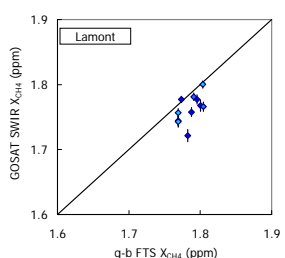
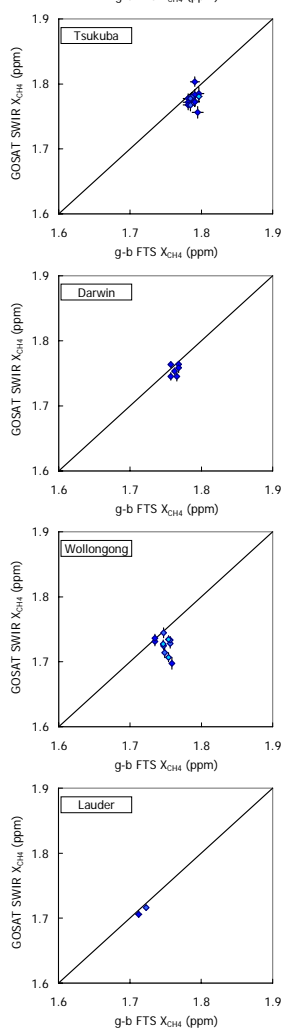

Fig. 6. Continued.

the hemispheres is small in October. The difference of $X_{\mathrm{CO}_{2}}$ between April and October is about $5 \mathrm{ppm}$ in the northern mid latitudes for both data sets. The zonal means of GOSAT data are reasonably consistent with those of the reference values, apart from the overall biases.

Figure 9 shows latitudinal distributions of monthly means of zonal averaged GOSAT SWIR and g-b FTS data of $X_{\mathrm{CH}_{4}}$ for April and October 2009. $X_{\mathrm{CH}_{4}}$ is characterized by relatively high concentrations in the Northern Hemisphere in April and October. Moreover, the bias is smaller than that of $X_{\mathrm{CO}_{2}}$. In particular, the concentration of $X_{\mathrm{CH}_{4}}$ of GOSAT data is in good agreement with that of g-b FTS sites in April. Both $X_{\mathrm{CH}_{4}}$ data in October show a similar distribution.

\section{Discussion}

In this study, we validated the GOSAT TANSO-FTS SWIR $X_{\mathrm{CO}_{2}}$ and $X_{\mathrm{CH}_{4}}$ against the TCCON g-b FTS instruments. In Ver.01.xx, the influence of aerosols has been markedly

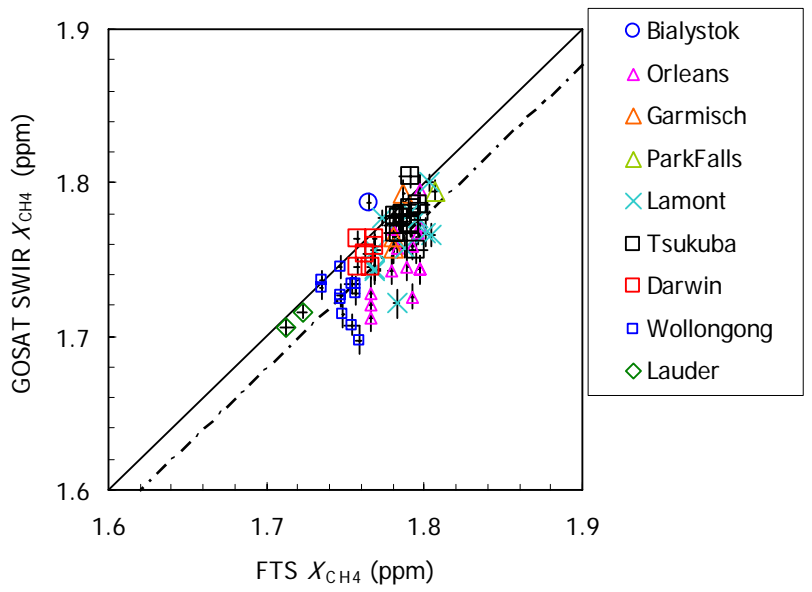

Fig. 7. Scatter diagram between GOSAT TANSO-FTS SWIR and g-b FTS $X_{\mathrm{CH}_{4}}$ at all FTS sites.

reduced compared with earlier versions of the retrievals (Yokota et al., 2009). The earlier versions (Ver.00.yy) used only band 2 of TANSO-FTS and retrieved $\mathrm{CO}_{2}$ and $\mathrm{CH}_{4}$ columns separately and estimates $X_{\mathrm{CO}_{2}}$ and $X_{\mathrm{CH}_{4}}$ using a dry-air column calculated from meteorological data analyzed by the Japan Meteorological Agency. Over the Sahara Desert and Arabian Peninsula and their surrounding areas, apparent high values of $X_{\mathrm{CO}_{2}}$ and $X_{\mathrm{CH}_{4}}$ were retrieved due to the influences of dust particles. In Ver.01.xx released in August 2010, bands 1 and 2 of TANSO-FTS were used for simultaneous retrieval of $\mathrm{CO}_{2}$ and $\mathrm{CH}_{4}$ columns with surface pressure. Therefore, the apparent high values of $X_{\mathrm{CO}_{2}}$ and $X_{\mathrm{CH}_{4}}$ almost disappeared over the Sahara Desert and their surrounding areas thanks to the correction of the extended optical paths by the elevated dust particles.

However, bias due to aerosols and thin cirrus clouds still exists because of the anomalously low $X_{\mathrm{CO}_{2}}$ retrievals (Fig. 2). In the future, we plan to investigate interferences by aerosols and thin cirrus clouds using aerosol lidars and/or sky-radiometers at selected FTS sites.

The negative bias of about $9 \mathrm{ppm}$ or $2.3 \%$ in the GOSAT TANSO-FTS SWIR data of $X_{\mathrm{CO}_{2}}$ is not still understood. It may result from unknown spectroscopic parameters of $\mathrm{O}_{2}$ and $\mathrm{CO}_{2}$ or error in the TANSO-FTS calibration. In the case of the GOSAT SWIR data of $X_{\mathrm{CH}_{4}}$, the negative bias decreased in the Ver.01.xx compared with the earlier Ver.00.yy when the spectroscopic parameters were changed from Lyulin et al. (2009) to HITRAN 2008 database (Rothman et al., 2009). Therefore it is important to further examine the spectroscopic parameters of $\mathrm{O}_{2}, \mathrm{CO}_{2}$ and $\mathrm{CH}_{4}$.

Some instrumental issues occurred since the launch of GOSAT, which could also contribute to the biases. The sampling laser wavelength of TANSO-FTS shifted in time probably due to the change of the $1.31-\mu \mathrm{m}$ distributed-feedback laser cavity length. The sensitivity of band 1 decreased after 

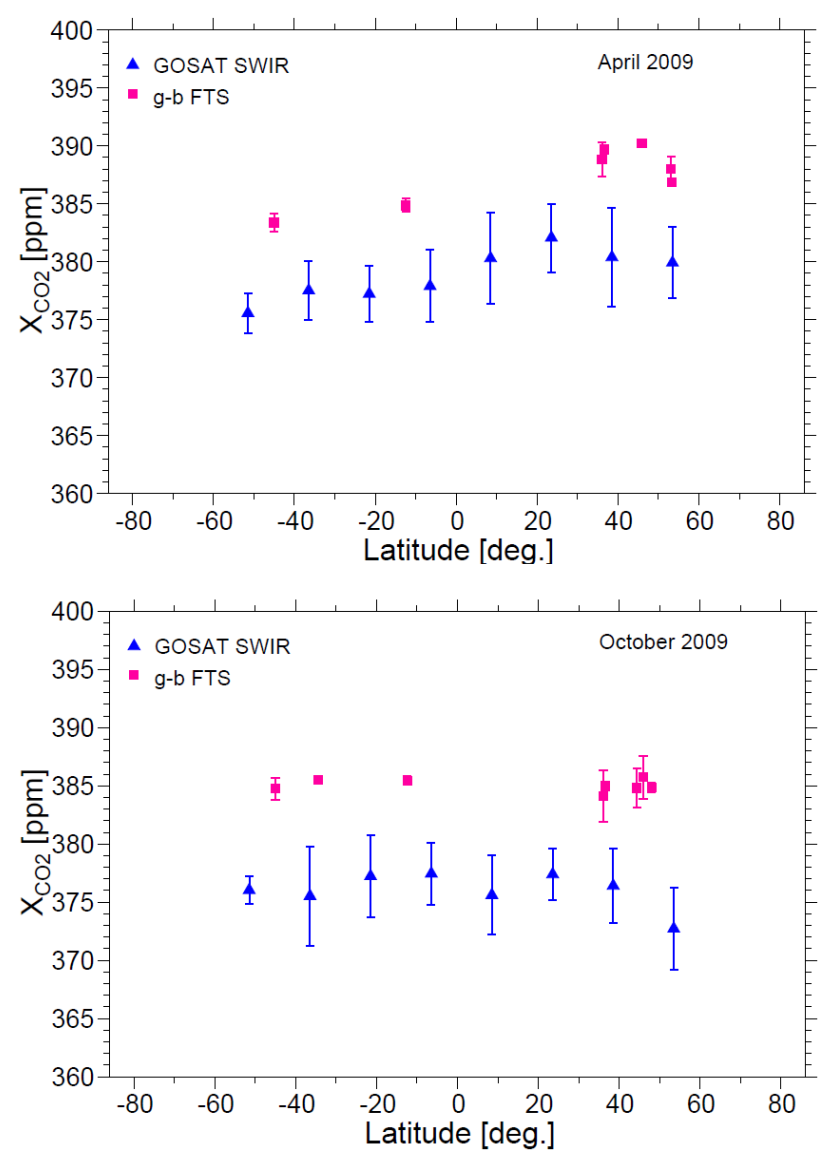

Fig. 8. Latitudinal distributions of monthly means of zonal averaged GOSAT $X_{\mathrm{CO}_{2}}$ for each 15 latitudinal band in April and October 2009 (blue triangles). The monthly means of g-b FTS data observed during local time of about 12:30-13:30 hour are shown by pink squares. Vertical bars indicate the standard deviation.

the launch. These effects are corrected before retrieving $X_{\mathrm{CO}_{2}}$ and $X_{\mathrm{CH}_{4}}$. A TANSO-FTS pointing error occurred when the pointing mirror was moved largely to the alongtrack direction. This error causes the mismatch of the field of views between CAI and TANSO-FTS, and misleads the cloud screening algorithm. However, in the case of the special point observation mode of TANSO-FTS to $g$-b FTS sites, the mismatch should be small.

The standard deviation of the GOSAT SWIR $X_{\mathrm{CO}_{2}}$ and $X_{\mathrm{CH}_{4}}$ is about $1 \%(1 \sigma)$ after correcting the negative biases by $8.85 \mathrm{ppm}$ and $20.4 \mathrm{ppb}$, respectively, and it is larger than those of the g-b FTS data $(\sim 0.2 \%)$. The retrieval errors of $X_{\mathrm{CO}_{2}}$ and $X_{\mathrm{CH}_{4}}$ are on average $2 \mathrm{ppm}$ and $8 \mathrm{ppb}$ or about $0.5 \%$ respectively. This means that the other errors of about $0.5 \%$ are due to influences of factors such as aerosols and thin cirrus clouds. In the retrieval algorithm of Ver.01.xx, aerosols are assumed to exist homogeneously below 2-km altitude. In the near future retrieval algorithm, the vertical profiles of aerosols will be simultaneously retrieved with $X_{\mathrm{CO}_{2}}$
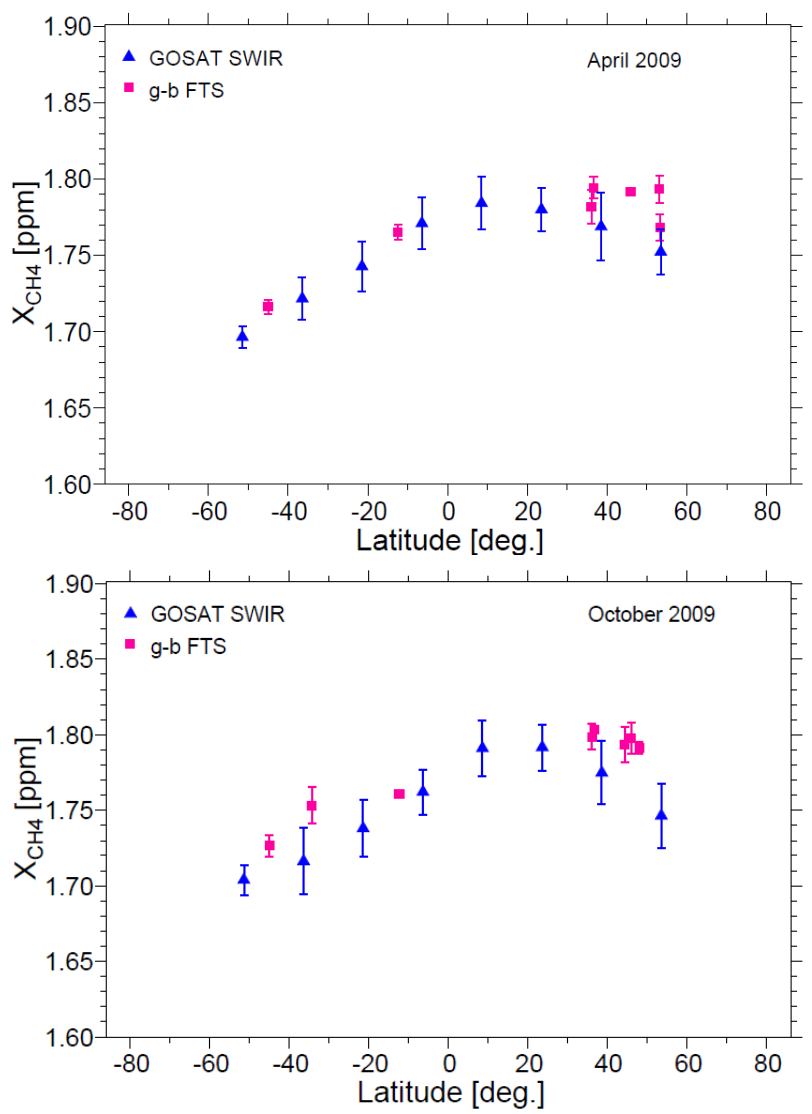

Fig. 9. As Fig. 8 but for $X_{\mathrm{CH}_{4}}$.

and $X_{\mathrm{CH}_{4}}$. This could decrease the standard deviation of the GOSAT $X_{\mathrm{CO}_{2}}$ and $X_{\mathrm{CH}_{4}}$. To what extent topographies surrounding g-b FTS sites influence the data quality, is not clear at present. We will investigate this effect in the near future.

\section{Conclusions}

The GOSAT TANSO-FTS SWIR data of $X_{\mathrm{CO}_{2}}$ and $X_{\mathrm{CH}_{4}}$ in the Version 01.xx were compared against reference data obtained with the TCCON g-b FTS sites. The GOSAT TANSO-FTS SWIR $X_{\mathrm{CO}_{2}}$ and $X_{\mathrm{CH}_{4}}$ were biased low by $8.85 \pm 4.75 \mathrm{ppm}(2.3 \pm 1.2 \%)$ and $20.4 \pm 18.9 \mathrm{ppb}$ $(1.2 \pm 1.1 \%)$ respectively versus the reference values. The standard deviation of the GOSAT SWIR $X_{\mathrm{CO}_{2}}$ and $X_{\mathrm{CH}_{4}}$ retrievals is considered to be about $1 \%(1 \sigma)$ after correcting the negative biases by $8.85 \mathrm{ppm}$ and $20.4 \mathrm{ppb}$, respectively.

Although $X_{\mathrm{CO}_{2}}$ is underestimated by approximately $9 \mathrm{ppm}$, the GOSAT retrievals and g-b FTS data show similar seasonal behaviors over the Northern Hemisphere: higher in spring and lower in autumn. The latitudinal distribution of zonal averaged GOSAT SWIR $X_{\mathrm{CO}_{2}}$ and $X_{\mathrm{CH}_{4}}$ is broadly consistent with that of the g-b FTS except for the larger negative biases in the GOSAT data. We plan further studies to address the negative bias of the GOSAT SWIR $X_{\mathrm{CO}_{2}}$ and $X_{\mathrm{CH}_{4}}$ as well as to better understand the influence of aerosols and thin cirrus clouds. 
Table A1. Left side: the average and one standard deviation $(1 \sigma)$ of the difference between GOSAT $X_{\mathrm{CO}_{2}}$ and g-b FTS $X_{\mathrm{CO}_{2}}$ for the nine TCCON sites. Right side: the average and one standard deviation $(1 \sigma)$ of the difference normalized to g-b FTS $X_{\mathrm{CO}_{2}}$ (given in percent). The GOSAT data were retrieved within \pm 2 degrees latitude/longitude box centered at each g-b FTS site and the g-b FTS data were the mean values measured within $\pm 1 \mathrm{~h}$ of GOSAT overpass time.

\begin{tabular}{l|rrr|cr}
\hline \multirow{2}{*}{ Sites } & $\begin{array}{r}\left(\mathrm{GOSAT} \text { SWIR } X_{\mathrm{CO}_{2}}\right)- \\
\left(\mathrm{g}-\mathrm{b} \text { FTS } X_{\mathrm{CO}_{2}}\right)\end{array}$ & $\begin{array}{c}{\left[\left(\mathrm{GOSAT} \mathrm{SWIR} X_{\mathrm{CO}_{2}}\right)-\right.} \\
\left.\left(\mathrm{g}-\mathrm{b} \text { FTS } X_{\mathrm{CO}_{2}}\right)\right] / \\
\left(\mathrm{g}-\mathrm{b} \text { FTS } X_{\mathrm{CO}_{2}}\right)\end{array}$ \\
\cline { 2 - 6 } & $\begin{array}{r}\text { Number } \\
\text { of data }\end{array}$ & $\begin{array}{r}\text { Average } \\
(\mathrm{ppm})\end{array}$ & $1 \sigma$ & $\begin{array}{c}\text { Average } \\
(\mathrm{ppm})\end{array}$ & $1 \sigma$ \\
\hline Bialystok & 3 & -6.68 & 10.04 & -1.72 & $(\%)$ \\
Orléans & 18 & -13.01 & 3.59 & -3.37 & 0.93 \\
Garmisch & 3 & -7.71 & 3.24 & -1.98 & 0.82 \\
Park Falls & 14 & -7.72 & 4.11 & -1.99 & 1.06 \\
Lamont & 126 & -8.28 & 3.88 & -2.13 & 1.00 \\
Tsukuba & 23 & -6.09 & 2.77 & -1.57 & 0.71 \\
Darwin & 9 & -7.83 & 3.39 & -2.03 & 0.88 \\
Wollongong & 57 & -9.24 & 5.38 & -2.39 & 1.39 \\
Lauder & 3 & -9.70 & 3.86 & -2.52 & 0.99 \\
\hline All data & 256 & -8.57 & 4.44 & -2.21 & 1.15 \\
\hline
\end{tabular}

\section{Appendix A}

\section{Comparison of GOSAT and g-b FTS data within $\pm \mathbf{2}$ degrees and $\pm \mathbf{1 ~ h}$}

We performed comparison of the GOSAT data retrieved within \pm 2 degrees latitude/longitude box centered at each g$b$ FTS site and the mean values of the g-b FTS data measured within $\pm 1 \mathrm{~h}$ of GOSAT overpass time.

The time series of the GOSAT and g-b FTS data for $X_{\mathrm{CO}_{2}}$ are shown on the left and their scatter diagrams on the right in Fig. A1. Figure A2 shows the scatter diagram between the GOSAT data and the g-b FTS data for all sites, and the slope of the regression line with no intercept is 0.978 with a correlation coefficient of 0.319 and Table A1 summarizes the difference of the GOSAT data to the g-b FTS data at each site. The difference of the GOSAT data to the g-b FTS data is $-8.57 \pm 4.44 \mathrm{ppm}$ or $-2.2 \pm 1.2 \%$.

The time series of the GOSAT and g-b FTS data for $X_{\mathrm{CH}_{4}}$ are shown on the left and their scatter diagrams on the right in Fig. A3. Figure A4 shows the scatter diagram between the GOSAT data and the g-b FTS data for all sites. The slope of the regression line with no intercept is 0.991 and the correlation coefficient is 0.794 . The difference between the GOSAT data and the g-b FTS data at each site is shown in Table A2. The difference of the GOSAT data to the g-b FTS data is $-15.8 \pm 22.3 \mathrm{ppb}$ or $-0.89 \pm 1.3 \%$.
Table A2. As in Table A1 except for $X_{\mathrm{CH}_{4}}$.

\begin{tabular}{l|rrr|cr}
\hline Sites & $\begin{array}{r}\left.\text { GOSAT SWIR } X_{\mathrm{CH}_{4}}\right)- \\
\left(\mathrm{g}-\mathrm{b} \mathrm{FTS} X_{\mathrm{CH}_{4}}\right)\end{array}$ & $\begin{array}{c}{\left[\left(\mathrm{GOSAT} \mathrm{SWIR} X_{\mathrm{CH}_{4}}\right)-\right.} \\
\left.\left(\mathrm{g}-\mathrm{b} \text { FTS } X_{\mathrm{CH}_{4}}\right)\right] / \\
\left(\mathrm{g}-\mathrm{b} \text { FTS } X_{\mathrm{CH}_{4}}\right)\end{array}$ \\
\cline { 2 - 6 } & $\begin{array}{r}\text { Number } \\
\text { of data }\end{array}$ & $\begin{array}{r}\text { Average } \\
(\mathrm{ppm})\end{array}$ & $\begin{array}{r}1 \sigma \\
(\mathrm{ppm})\end{array}$ & $\begin{array}{c}\text { Average } \\
(\%)\end{array}$ & $(\%)$ \\
\hline Bialystok & 3 & -0.0107 & 0.0306 & -0.61 & 1.73 \\
Orléans & 18 & -0.0383 & 0.0191 & -2.14 & 1.07 \\
Garmisch & 3 & -0.0111 & 0.0170 & -0.62 & 0.95 \\
Park Falls & 14 & -0.0116 & 0.0213 & -0.65 & 1.19 \\
Lamont & 126 & -0.0108 & 0.0213 & -0.60 & 1.18 \\
Tsukuba & 23 & -0.0101 & 0.0135 & -0.57 & 0.75 \\
Darwin & 9 & -0.0153 & 0.0141 & -0.87 & 0.80 \\
Wollongong & 57 & -0.0237 & 0.0243 & -1.36 & 1.39 \\
Lauder & 3 & -0.0170 & 0.0179 & -0.98 & 1.03 \\
\hline All data & 256 & -0.0158 & 0.0223 & -0.89 & 1.26 \\
\hline
\end{tabular}

(a)
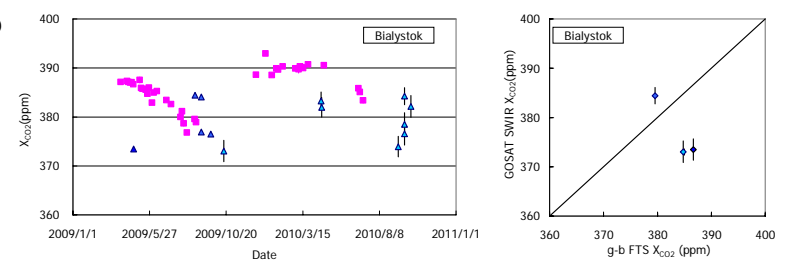

(b)
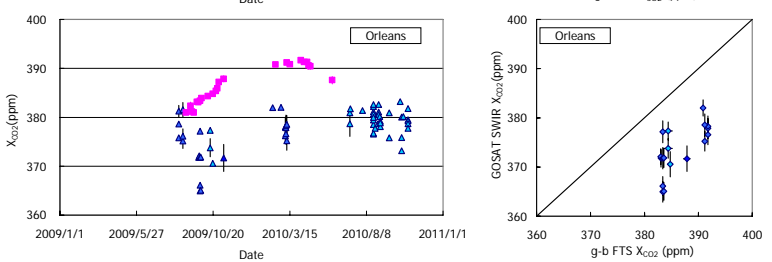

(c)
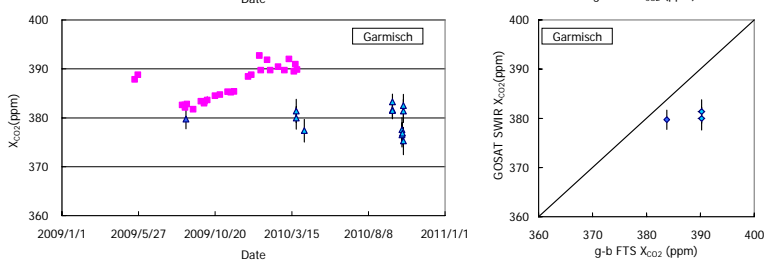

(d)
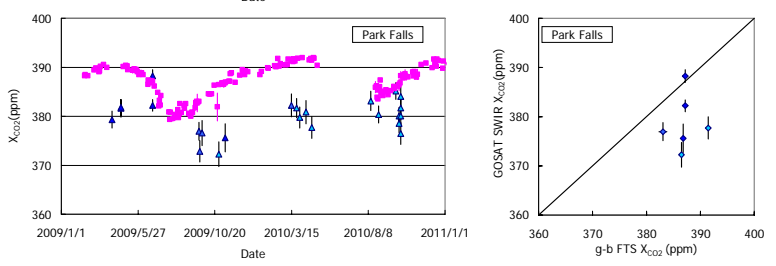

Fig. A1. Time series of GOSAT TANSO-FTS SWIR (blue triangles) and g-b FTS (pink squares) $X_{\mathrm{CO}_{2}}$ and their scatter diagrams for (a) Bialystok, (b) Orléans, (c) Garmisch, (d) Park Falls, (e) Lamont, (f) Tsukuba, (g) Darwin, (h) Wollongong, and (i) Lauder. The GOSAT data were retrieved within \pm 2 degrees latitude/longitude box centered at each g-b FTS site and the g-b FTS data were the mean values measured within $\pm 1 \mathrm{~h}$ of GOSAT overpass time. 
(e)

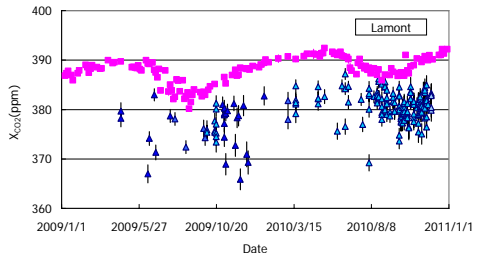

(f)

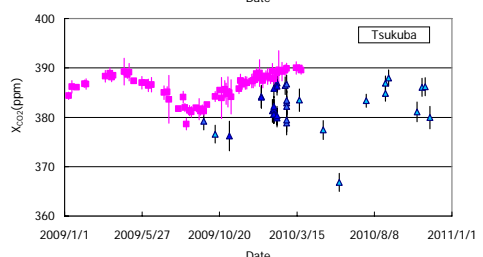

(g)

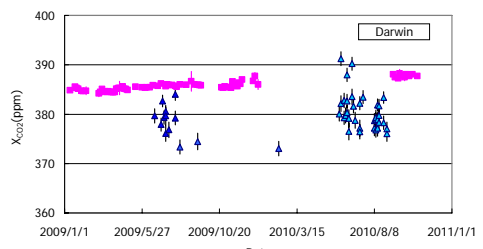

(h)
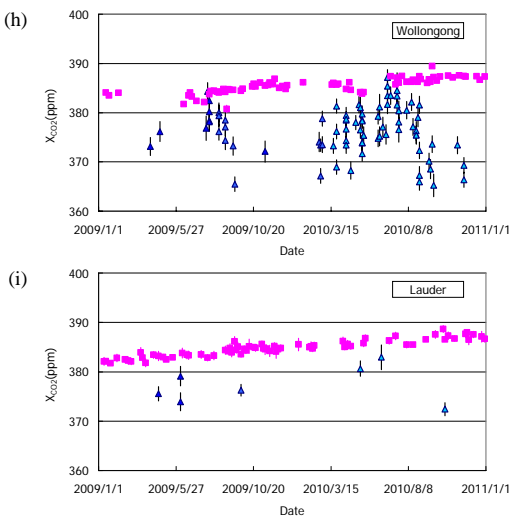
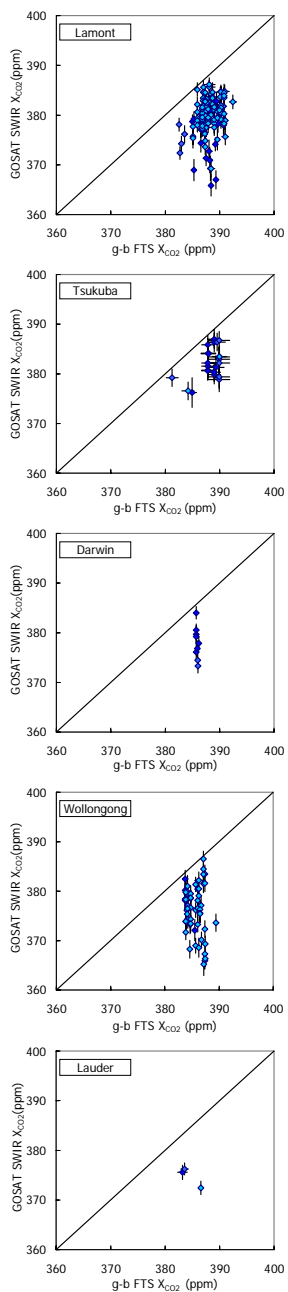

Fig. A1. Continued.

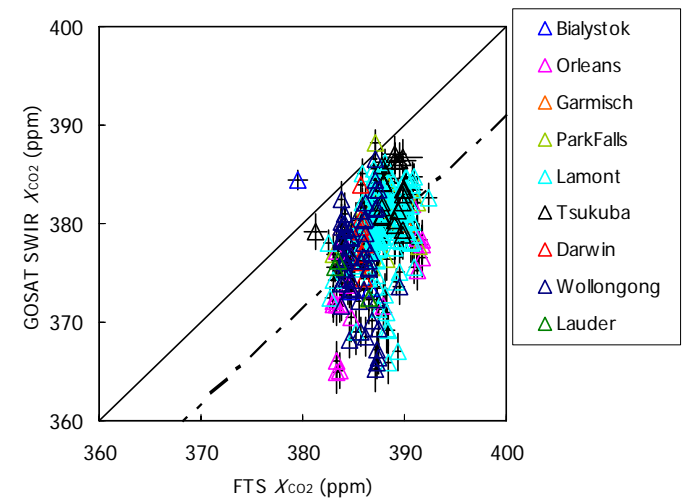

Fig. A2. Scatter diagram between GOSAT and g-b FTS $X_{\mathrm{CO}_{2}}$ at all FTS sites. The GOSAT data were retrieved within \pm 2 degrees latitude/longitude box centered at each g-b FTS site and the g-b FTS data were the mean values measured within $\pm 1 \mathrm{~h}$ of GOSAT overpass time.

(a)
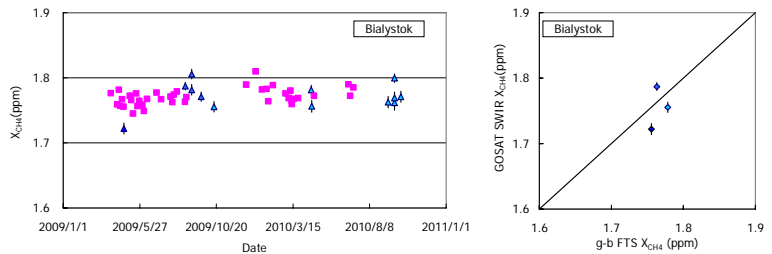

(b)
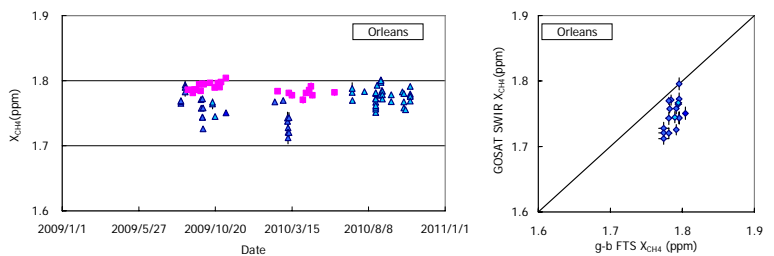

(c)
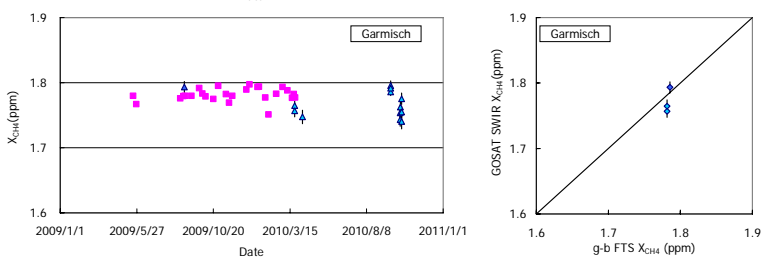

(d)
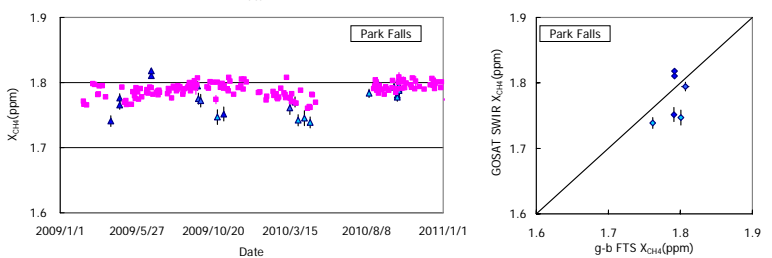

Fig. A3. Time series of GOSAT TANSO-FTS SWIR (blue triangles) and g-b FTS (pink squares) $X_{\mathrm{CH}_{4}}$ and their scatter diagrams for (a) Bialystok, (b) Orléans, (c) Garmisch, (d) Park Falls, (e) Lamont, (f) Tsukuba, (g) Darwin, (h) Wollongong, and (i) Lauder. The GOSAT data were retrieved within \pm 2 degrees latitude/longitude box centered at each g-b FTS site and the g-b FTS data were the mean values measured within $\pm 1 \mathrm{~h}$ of GOSAT overpass time.

\section{Appendix B}

\section{Comparison of GOSAT and g-b FTS data within \pm 5 degrees and $\pm \mathbf{1 ~ h}$}

We performed comparison of the GOSAT data retrieved within \pm 5 degrees latitude/longitude box centered at each g$b$ FTS site and the mean values of the g-b FTS data measured within $\pm 1 \mathrm{~h}$ of GOSAT overpass time.

The time series of the GOSAT and g-b FTS data for $X_{\mathrm{CO}_{2}}$ are shown on the left and their scatter diagrams on the right in Fig. B1.

Figure B2 shows the scatter diagram between the GOSAT data and the g-b FTS data for all sites, and the slope of the regression line with no intercept is 0.979 with a correlation coefficient of 0.285 and Table B1 summarizes the difference of the GOSAT data to the g-b FTS data at each site. 
(e)

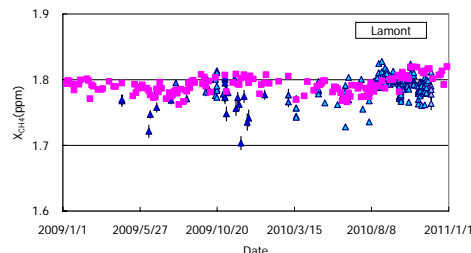

(f)

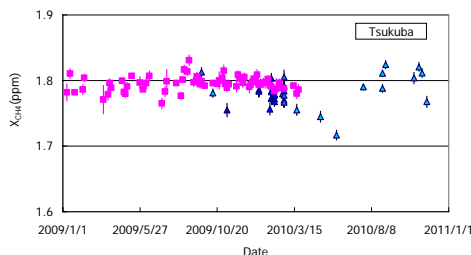

(g)

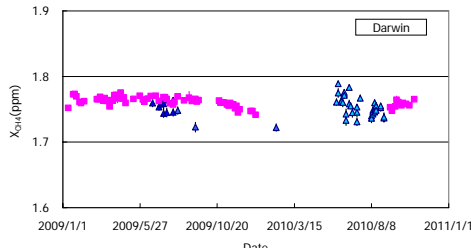

(h)

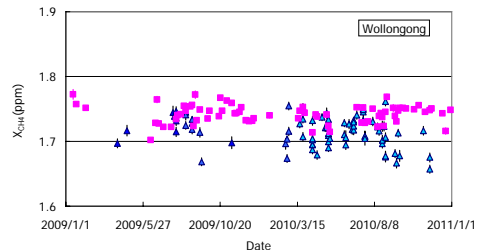

(i)

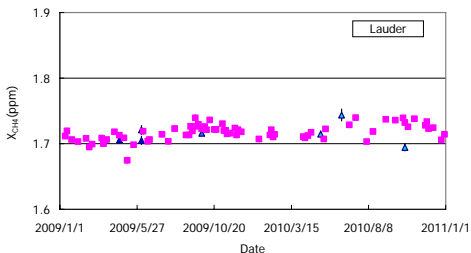

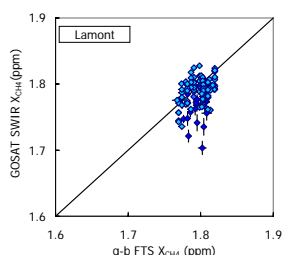
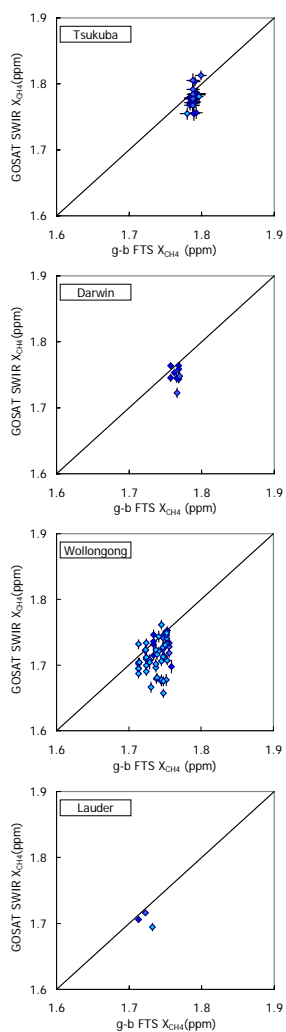

Fig. A3. Continued.

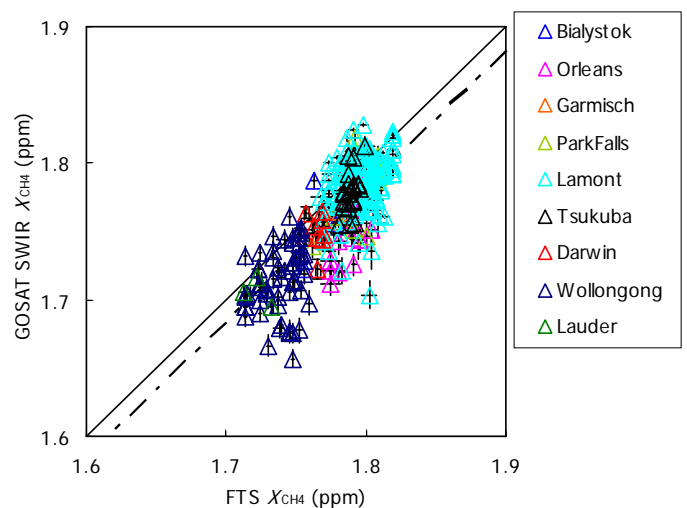

Fig. A4. Scatter diagram between GOSAT and g-b FTS $X_{\mathrm{CH}_{4}}$ at all FTS sites. The GOSAT data were retrieved within \pm 2 degrees latitude/longitude box centered at each g-b FTS site and the g-b FTS data were the mean values measured within $\pm 1 \mathrm{~h}$ of GOSAT overpass time.

Table B1. Left side: the average and one standard deviation $(1 \sigma)$ of the difference between GOSAT $X_{\mathrm{CO}_{2}}$ and g-b FTS $X_{\mathrm{CO}_{2}}$ for the nine TCCON sites. Right side: the average and one standard deviation $(1 \sigma)$ of the difference normalized to g-b FTS $X_{\mathrm{CO}_{2}}$ (given in percent). The GOSAT data were retrieved within \pm 5 degrees latitude/longitude box centered at each g-b FTS site and the g-b FTS data were the mean values measured within $\pm 1 \mathrm{~h}$ of GOSAT overpass time.

\begin{tabular}{l|rrr|rr}
\hline \multirow{2}{*}{ Sites } & $\begin{array}{r}\left(\mathrm{GOSAT} \mathrm{SWIR} X_{\mathrm{CO}_{2}}\right)- \\
\left(\mathrm{g}-\mathrm{b} \text { FTS } X_{\mathrm{CO}_{2}}\right)\end{array}$ & $\begin{array}{r}{\left[\left(\mathrm{GOSAT} \mathrm{SWIR} X_{\mathrm{CO}_{2}}\right)-\right.} \\
\left.\left(\mathrm{g}-\mathrm{b} \text { FTS } X_{\mathrm{CO}_{2}}\right)\right] / \\
\left(\mathrm{g}-\mathrm{b} \text { FTS } X_{\mathrm{CO}_{2}}\right)\end{array}$ \\
\cline { 2 - 6 } & $\begin{array}{r}\text { Number } \\
\text { of data }\end{array}$ & $\begin{array}{r}\text { Average } \\
(\mathrm{ppm})\end{array}$ & $\begin{array}{r}1 \sigma \\
(\mathrm{ppm})\end{array}$ & $\begin{array}{r}\text { Average } \\
(\%)\end{array}$ & $\begin{array}{c}(\%) \\
\text { Bialystok }\end{array}$ \\
\cline { 2 - 6 } Orléans & 26 & -6.76 & 4.38 & -1.75 & 1.13 \\
Garmisch & 59 & -10.24 & 3.75 & -2.65 & 0.97 \\
Park Falls & 15 & -6.58 & 2.35 & -1.71 & 0.60 \\
Lamont & 513 & -8.24 & 4.07 & -2.13 & 1.05 \\
Tsukuba & 29 & -5.61 & 3.33 & -1.44 & 0.92 \\
Darwin & 72 & -7.41 & 3.04 & -1.92 & 0.86 \\
Wollongong & 143 & -8.72 & 5.22 & -2.26 & 1.35 \\
Lauder & 5 & -7.02 & 4.57 & -1.83 & 1.18 \\
\hline All data & 966 & -8.25 & 3.97 & -2.10 & 1.02 \\
\hline
\end{tabular}

Table B2. As in Table B1 except for $X_{\mathrm{CH}_{4}}$.

\begin{tabular}{|c|c|c|c|c|c|}
\hline \multirow[t]{2}{*}{ Sites } & \multicolumn{3}{|c|}{$\begin{array}{c}\left(\text { GOSAT SWIR } X_{\mathrm{CH}_{4}}\right)- \\
\left(\mathrm{g}-\mathrm{b} \text { FTS } X_{\mathrm{CH}_{4}}\right)\end{array}$} & \multicolumn{2}{|c|}{$\begin{array}{c}{\left[\left(\mathrm{GOSAT} \mathrm{SWIR} X_{\mathrm{CH}_{4}}\right)-\right.} \\
\left.\left(\mathrm{g}-\mathrm{b} \text { FTS } X_{\mathrm{CH}_{4}}\right)\right] / \\
\left(\mathrm{g}-\mathrm{b} \text { FTS } X_{\mathrm{CH}_{4}}\right)\end{array}$} \\
\hline & $\begin{array}{l}\text { Number } \\
\text { of data }\end{array}$ & $\begin{array}{r}\text { Average } \\
(\mathrm{ppm})\end{array}$ & $\begin{array}{r}1 \sigma \\
(\mathrm{ppm})\end{array}$ & $\begin{array}{r}\text { Average } \\
(\%)\end{array}$ & $\begin{array}{l}1 \sigma \\
(\%)\end{array}$ \\
\hline Bialystok & 26 & -0.0072 & 0.0238 & -0.41 & 1.35 \\
\hline Orléans & 59 & -0.0230 & 0.0183 & -1.29 & 1.03 \\
\hline Garmisch & 15 & 0.0032 & 0.0152 & 0.18 & 0.85 \\
\hline Park Falls & 104 & -0.0166 & 0.0225 & -0.92 & 1.25 \\
\hline Lamont & 513 & -0.0132 & 0.0230 & -0.73 & 1.28 \\
\hline Tsukuba & 29 & -0.0077 & 0.0165 & -0.43 & 0.92 \\
\hline Darwin & 72 & -0.0140 & 0.0123 & -0.80 & 0.70 \\
\hline Wollongong & 143 & -0.0218 & 0.0253 & -1.25 & 1.45 \\
\hline Lauder & 5 & -0.0030 & 0.0230 & -0.17 & 1.33 \\
\hline All data & 966 & -0.0148 & 0.0226 & -0.83 & 1.27 \\
\hline
\end{tabular}

The difference of the GOSAT data to the g-b FTS data is $-8.25 \pm 3.97 \mathrm{ppm}$ or $-2.1 \pm 1.0 \%$.

The time series of the GOSAT and g-b FTS data for $X_{\mathrm{CH}_{4}}$ are shown on the left and their scatter diagrams on the right in Fig. B3. Figure B4 shows the scatter diagram between the GOSAT data and the g-b FTS data for all sites. The slope of the regression line with no intercept is 0.992 and the correlation coefficient is 0.712 . The difference between the GOSAT data and the g-b FTS data at each site is shown in Table B2. The difference of the GOSAT data to the $\mathrm{g}$-b FTS data is $-14.8 \pm 22.6 \mathrm{ppb}$ or $-0.83 \pm 1.3 \%$. 
(a)

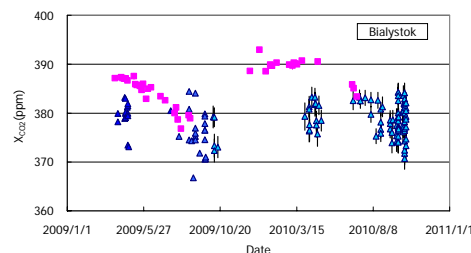

(b)

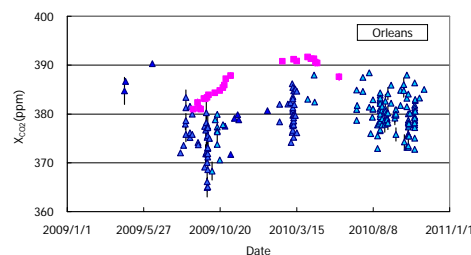

(c)

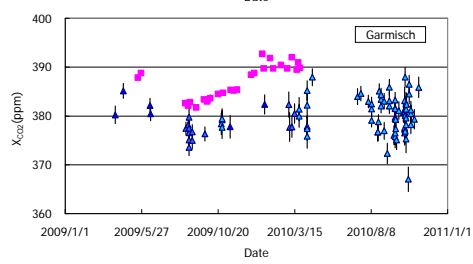

(d)

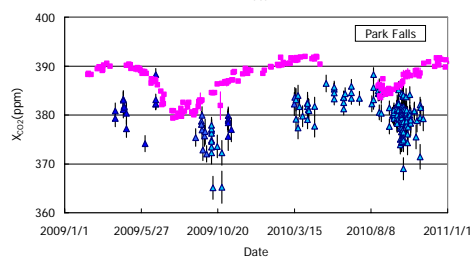

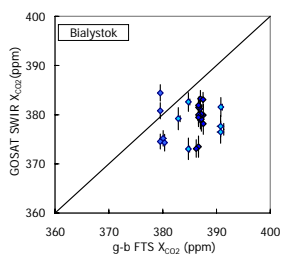
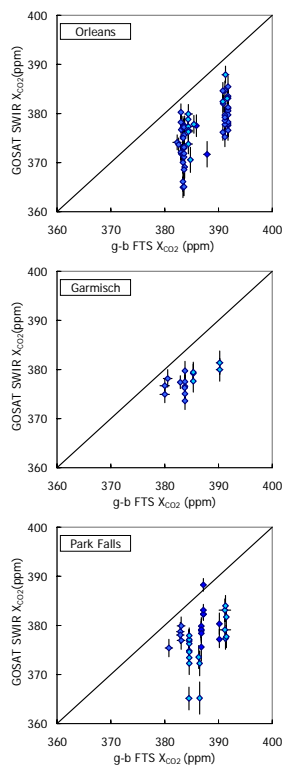

Fig. B1. Time series of GOSAT TANSO-FTS SWIR (blue triangles) and g-b FTS (pink squares) $X_{\mathrm{CO}_{2}}$ and their scatter diagrams for (a) Bialystok, (b) Orléans, (c) Garmisch, (d) Park Falls, (e) Lamont, (f) Tsukuba, (g) Darwin, (h) Wollongong, and (i) Lauder. The GOSAT data were retrieved within \pm 5 degrees latitude/longitude box centered at each g-b FTS site and the g-b FTS data were the mean values measured within $\pm 1 \mathrm{~h}$ of GOSAT overpass time.

Acknowledgements. We express our sincere thanks to the members of the NIES GOSAT project office, data algorithm team, atmospheric transport modeling team for their useful comments. We thank Nobuyuki Kikuchi in NIES and Komei Yamaguchi in the Japan Weather Association for plotting the data. We would like to thank anonymous referees and the associated editor for improving this paper. This work was funded by the Ministry of the Environment in Japan. We also thank NASA's Terrestrial Ecology Program and the Orbiting Carbon Observatory for their support of TCCON, and acknowledge support from the EU within the projects GEOMON and IMECC. The Lauder TCCON measurements are funded by New Zealand Foundation for Research, Science and Technology contracts CO1X0204 and CO1X0406. We thank the members of RAMCES team at LSCE (Gif-sur-Yvette) for maintaining the FTS at the Trainou station and providing station logistics.

Edited by: G. Stiller

(e)

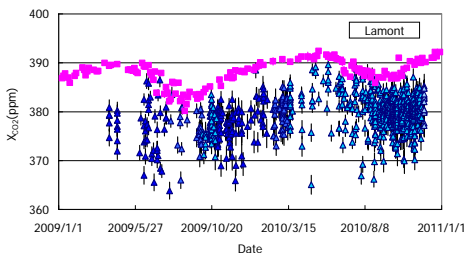

(f)
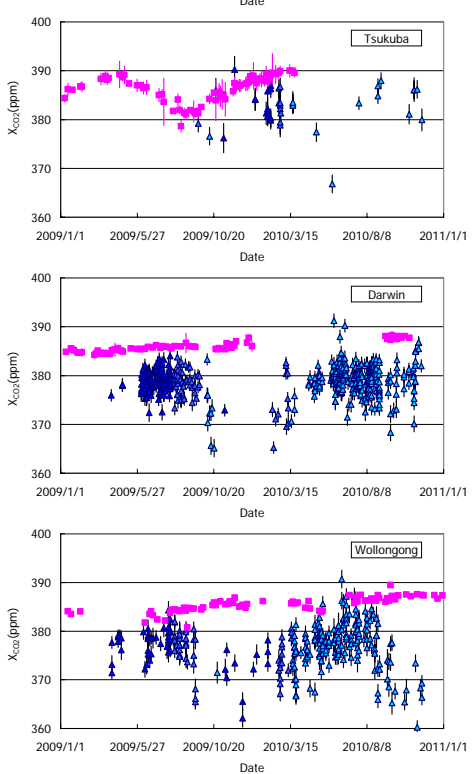

(i)
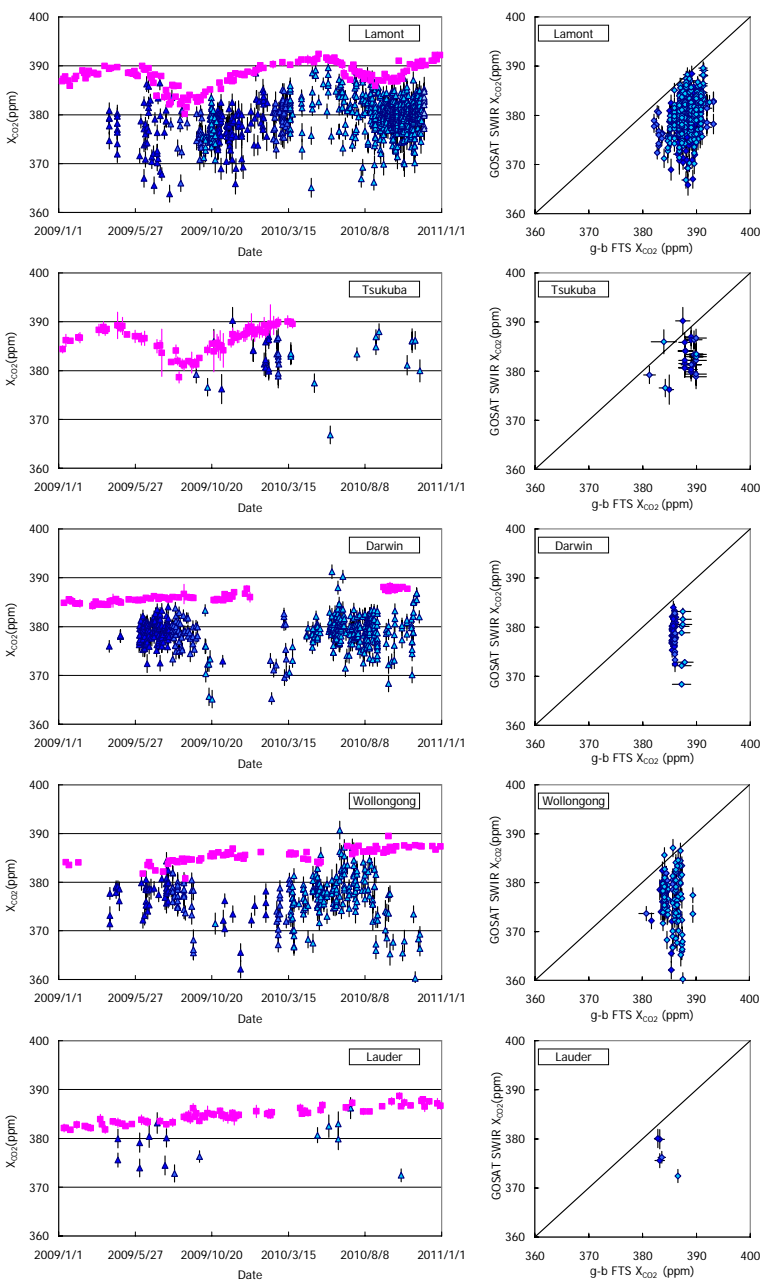

Fig. B1. Continued.

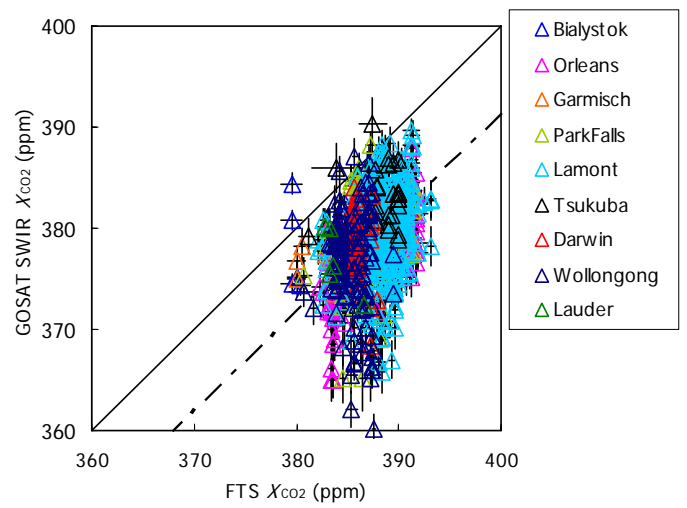

Fig. B2. Scatter diagram between GOSAT and g-b FTS $X_{\mathrm{CO}_{2}}$ at all FTS sites. The GOSAT data were retrieved within \pm 5 degrees latitude/longitude box centered at each g-b FTS site and the g-b FTS data were the mean values measured within $\pm 1 \mathrm{~h}$ of GOSAT overpass time. 
(a)

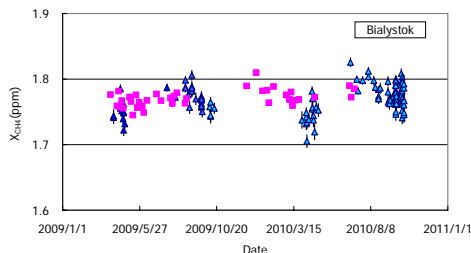

(b)

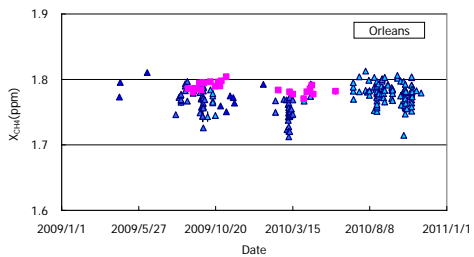

(c)

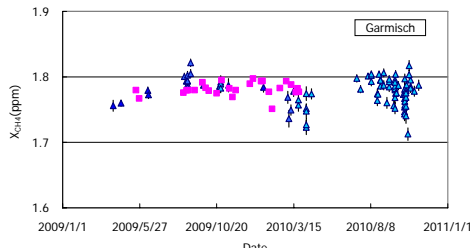

(d)

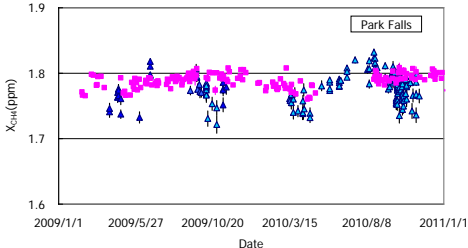

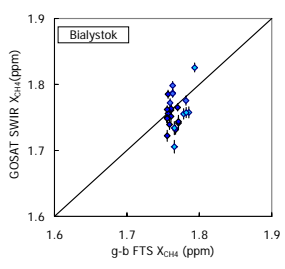
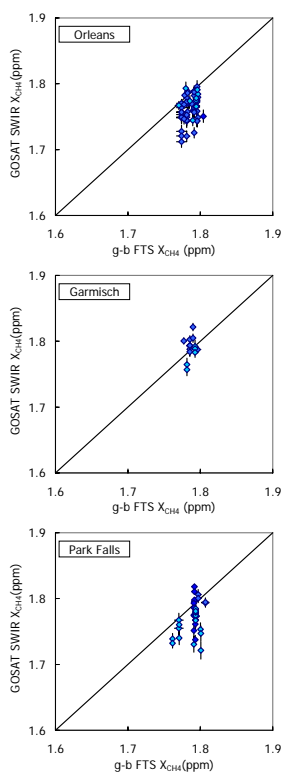

Fig. B3. Time series of GOSAT TANSO-FTS SWIR (blue triangles) and g-b FTS (pink squares) $X_{\mathrm{CH}_{4}}$ and their scatter diagrams for (a) Bialystok, (b) Orléans, (c) Garmisch, (d) Park Falls, (e) Lamont, (f) Tsukuba, (g) Darwin, (h) Wollongong, and (i) Lauder. The GOSAT data were retrieved within \pm 5 degrees latitude/longitude box centered at each g-b FTS site and the g-b FTS data were the mean values measured within $\pm 1 \mathrm{~h}$ of GOSAT overpass time.

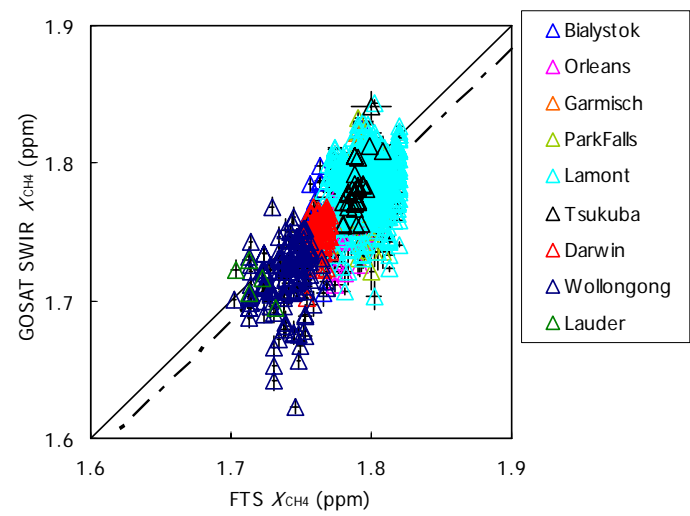

Fig. B4. Scatter diagram between GOSAT and g-b FTS $X_{\mathrm{CH}_{4}}$ at all FTS sites. The GOSAT data were retrieved within \pm 5 degrees latitude/longitude box centered at each g-b FTS site and the g-b FTS data were the mean values measured within $\pm 1 \mathrm{~h}$ of GOSAT overpass time.

(e)

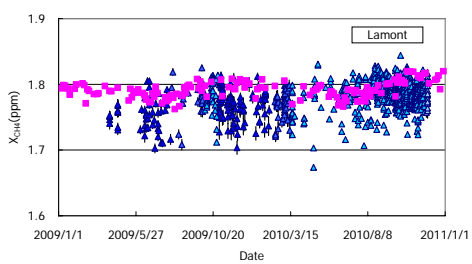

(f)

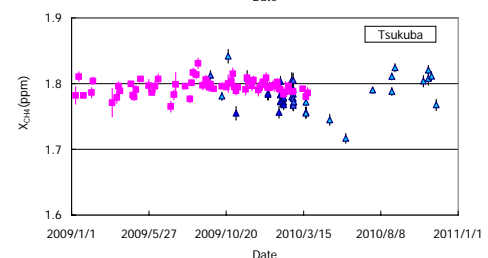

(g)

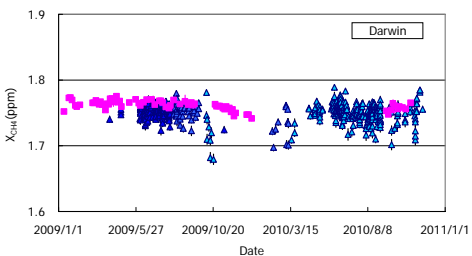

(h)
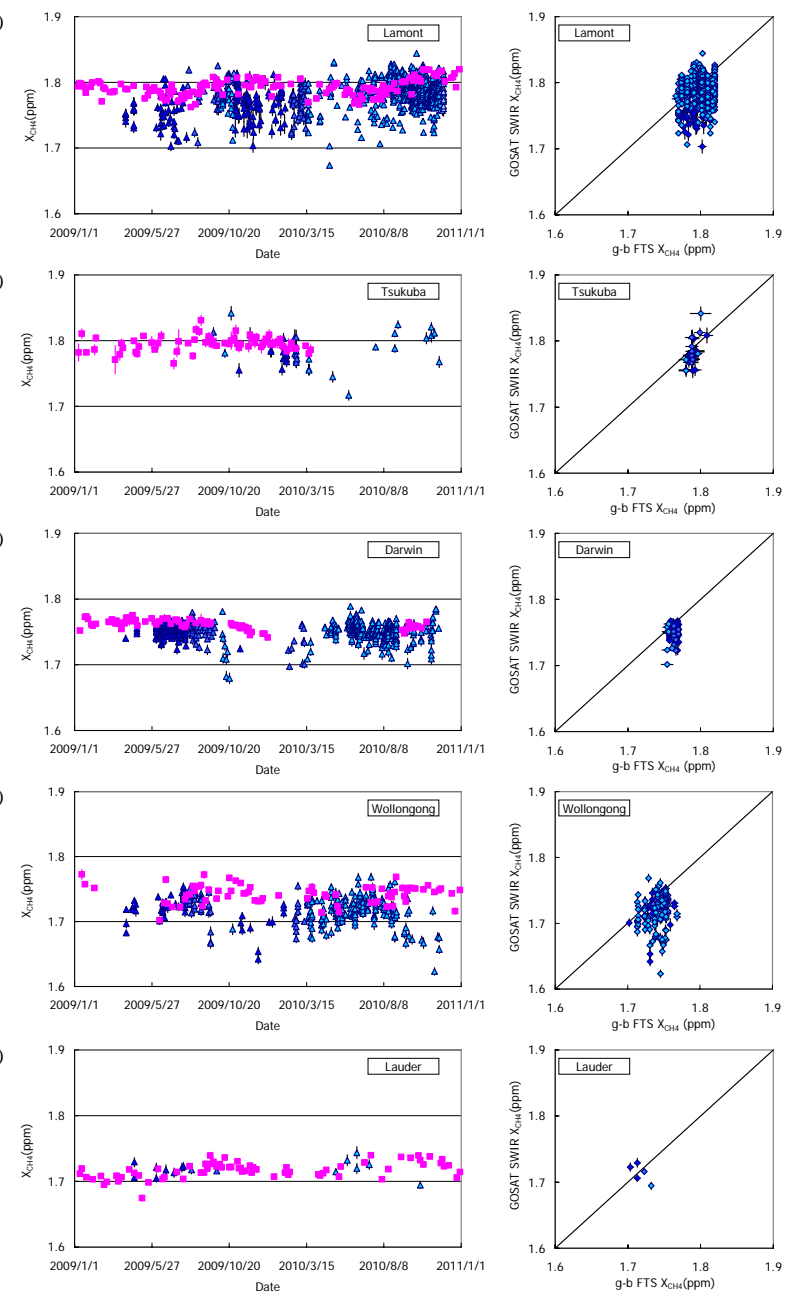

Fig. B3. Continued.

\section{References}

Baker, D. F., Law, R. M., Gurney, K. R., Rayner, P., Peylin, P., Denning, A. S., Bousquet, P., Bruhwiler, L., Chen, Y. H., Ciais, P., Fung, I. Y., Heimann, M., John, J., Maki, T., Maksyutov, S., Masarie, K., Prather, M., Pak, B., Taguchi, S., and Zhu, Z.: TransCom 3 inversion intercomparison: Impact of transport model errors on the interannual variability of regional $\mathrm{CO}_{2}$ fluxes, 1988-2003, Global Biogeochem. Cy., 20, GB1002, doi:10.1029/2004GB002439, 2006.

Bergamaschi, P., Frankenberg, C., Meirink, J. F., Krol, M., Dentener, F., Wagner, T., Platt, U., Kaplan, J. O., Körner, S., Heimann, M., Dlugokencky, E. J., and Goede, A.: Satellite chartography of atmospheric methane from SCIAMACHY on board ENVISAT: 2. Evaluation based on inverse model simulations, J. Geophys. Res., 112, D02304, doi:10.1029/2006JD007268, 2007.

Chahine, M., Barnet, C., Olsen, E. T., Chen, L., and Maddy, E.: On the determination of atmospheric minor gases by the method of vanishing partial derivatives with application to $\mathrm{CO}_{2}$, Geophys. Res. Lett., 32, L22803, doi:10.1029/2005GL024165, 2005.

Cox, P. M., Betts, R. A., Jones, C. D., Spall, S. A., and Totterdell, I. J.: Acceleration of global warming due to carbon-cycle feedbacks in a coupled climate model, Nature, 408, 184-187, 2000. 
Deutscher, N. M., Griffith, D. W. T., Bryant, G. W., Wennberg, P. O., Toon, G. C., Washenfelder, R. A., Keppel-Aleks, G., Wunch, D., Yavin, Y., Allen, N. T., Blavier, J.-F., Jiménez, R., Daube, B. C., Bright, A. V., Matross, D. M., Wofsy, S. C., and Park, S.: Total column $\mathrm{CO}_{2}$ measurements at Darwin, Australia - site description and calibration against in situ aircraft profiles, Atmos. Meas. Tech., 3, 947-958, doi:10.5194/amt-3-947-2010, 2010.

Dils, B., De Mazière, M., Müller, J. F., Blumenstock, T., Buchwitz, M., de Beek, R., Demoulin, P., Duchatelet, P., Fast, H., Frankenberg, C., Gloudemans, A., Griffith, D., Jones, N., Kerzenmacher, T., Kramer, I., Mahieu, E., Mellqvist, J., Mittermeier, R. L., Notholt, J., Rinsland, C. P., Schrijver, H., Smale, D., Strandberg, A., Straume, A. G., Stremme, W., Strong, K., Sussmann, R., Taylor, J., van den Broek, M., Velazco, V., Wagner, T., Warneke, T., Wiacek, A., and Wood, S.: Comparisons between SCIAMACHY and ground-based FTIR data for total columns of $\mathrm{CO}, \mathrm{CH}_{4}, \mathrm{CO}_{2}$ and $\mathrm{N}_{2} \mathrm{O}$, Atmos. Chem. Phys., 6, 1953-1976, doi:10.5194/acp6-1953-2006, 2006.

Dlugokencky, E. J., Bruhwiler, L., White, J. W. C., Emmons, L. K., Novelli, P. C., Montzka, S. A., Masarie, K. A., Lang, P. M., Crotwell, A. M., Miller, J. B., and Gatti, L. V.: Observational constraints on recent increases in the atmospheric $\mathrm{CH}_{4}$ burden, Geophys. Res. Lett., 36, L18803, doi:10.1029/2009GL039780, 2009.

Frankenberg, C., Meirink, J. F., Bergamaschi, P., Goede, A. P. H., Heimann, M., Körner, S., Platt, U., van Weele, M., and Wagner, T.: Satellite chartography of atmospheric methane from SCIAMACHY on board ENVISAT: Analysis of the years 2003 and 2004, J. Geophys. Res., 111, D07303, doi:10.1029/2005JD006235, 2006.

Houweling, S., Breon, F.-M., Aben, I., Rödenbeck, C., Gloor, M., Heimann, M., and Ciais, P.: Inverse modeling of $\mathrm{CO}_{2}$ sources and sinks using satellite data: a synthetic inter-comparison of measurement techniques and their performance as a function of space and time, Atmos. Chem. Phys., 4, 523-538, doi:10.5194/acp-4-523-2004, 2004.

Intergovernmental Panel on Climate Change (IPCC), Climate change 2007: The Physical Science Basis: Contribution of Working Group I to the Fourth Assessment Report of the Intergovernmental Panel on Climate Change, edited by: Solomon, S., Qin, D., Manning, M., Chen, Z., Marquis, M., Averyt, K. B., Tignor, M., and Miller, H. L., Cambridge University Press, Cambridge, UK and New York, NY, USA, 996 pp., 2007.

Ishida, H. and Nakajima, T. Y.: Development of an unbiased cloud detection algorithm for a spaceborne multispectral imager, J. Geophys. Res., 114, D07206, doi:10.1029/2008JD010710, 2009.

Kulawik, S. S., Jones, D. B. A., Nassar, R., Irion, F. W., Worden, J. R., Bowman, K. W., Machida, T., Matsueda, H., Sawa, Y., Biraud, S. C., Fischer, M. L., and Jacobson, A. R.: Characterization of Tropospheric Emission Spectrometer (TES) $\mathrm{CO}_{2}$ for carbon cycle science, Atmos. Chem. Phys., 10, 5601-5623, doi:10.5194/acp-10-5601-2010, 2010.

Kuze, A., Suto, H., Nakajima, M., and Hamazaki, T.: Thermal and near infrared sensor for carbon observation Fourier-transform spectrometer on the Greenhouse Gases Observing Satellite for greenhouse gases monitoring, Appl. Opt., 48, 6716-6733, 2009.

Lamouroux, J., Tran, H., Laraia, A. L., Gamache, R. R., Rothman, L. S., Gordon, I. E., and Hartmann, J.-M.: Updated database plus software for line-mixing in $\mathrm{CO}_{2}$ infrared spectra and their test using laboratory spectra in the $1.5-2.3 \mu \mathrm{m}$ region, J. Quant. Spectrosc. Ra., 111, 2321-2331, doi:10.1016/j.jqsrt.2010.03.006, 2010.

Lyulin, O. M., Nikitin, A. V., Perevalov, V. I., Morino, I., Yokota, T., Kumazawa, R., and Watanabe, T.: Measurements of $\mathrm{N}_{2}$ - and $\mathrm{O}_{2}$ broadening and shifting parameters of methane spectral lines in the 5550-6236 $\mathrm{cm}^{-1}$ region, J. Quant. Spectrosc. Ra., 110, 654668, doi:10.1016/j.jqsrt.2009.02.012, 2009.

Meirink, J. F., Eskes, H. J., and Goede, A. P. H.: Sensitivity analysis of methane emissions derived from SCIAMACHY observations through inverse modelling, Atmos. Chem. Phys., 6, 1275-1292, doi:10.5194/acp-6-1275-2006, 2006.

Messerschmidt, J., Macatangay, R., Notholt, J., Petri, C., Warneke, T., and Weinzierl, C.: Side by side measurements of $\mathrm{CO}_{2}$ by ground-based Fourier transform spectrometry (FTS), Tellus, 62B, 749-758, 2010.

Miller C. E., Crisp, D., DeCola, P. L., Olsen, S. C., Randerson, J. T., Michalak, A. M., Alkhaled, A., Rayner, P., Jacob, D. J., Suntharalingam, P., Jones, D. B. A., Denning, A. S., Nicholls, M. E., Doney, S. C., Pawson, S., Boesch, H., Connor, B. J., Fung, I. Y., O’Brien, D., Salawitch, R. J., Sander, S. P., Sen, B., Tans, P., Toon, G. C., Wennberg, P. O., Wofsy, S. C., Yung, Y. L., and Law, R. M.: Precision requirements for space-based $X_{\mathrm{CO}_{2}}$ data, J. Geophys. Res., 112, D10314, doi:10.1029/2006JD007659, 2007.

Ohyama, H., Morino, I., Nagahama, T., Machida, T., Suto, H., Oguma, H., Sawa, Y., Matsueda, H., Sugimoto, N., Nakane, H., and Nakagawa, K.: Column-averaged volume mixing ratio of $\mathrm{CO}_{2}$ measured with ground-based Fourier transform spectrometer at Tsukuba, J. Geophys. Res., 114, D18303, doi:10.1029/2008JD011465, 2009.

Rayner, P. J. and O'Brien, D. M.: The utility of remotely sensed $\mathrm{CO}_{2}$ concentration data in surface source inversions, Geophys. Res. Lett., 28, 175-178, 2001.

Rothman, L. S., Gordon, I. E., Barbe, A., Benner, D. C., Bernath, P. F., Birk, M., Boudon, V., Brown, L. R., Campargue, A., Champion, J.-P., Chance, K., Coudert, L. H., Dana, V., Devi, V. M., Fally, S., Flaud, J.-M. Gamache, R. R., Goldman, A., Jacquemart, D., Kleiner, I., Lacome, N., Lafferty, W. J., Mandin, J.-Y., Massie, S. T., Mikhailenko, S. N., Miller, C. E., Moazzen-Ahmadi, N., Naumenko, O. V., Nikitin, A. V., Orphal, J., Perevalov, V. I., Perrin, A., Predoi-Cross, A., Rinsland, C. P., Rotger, M., Šimečková, M., Smith, M. A. H., Sung, K., Tashkun, S. A., Tennyson, J., Toth, R. A., Vandaele, A. C., and Auwera, J. V.: The HITRAN 2008 molecular spectroscopic database, J. Quant. Spectrosc. Ra., 110, 533-572, doi:10.1016/j.jqsrt.2009.02.013, 2009.

Saitoh, N., Imasu, R., Ota, Y., and Niwa, Y.: $\mathrm{CO}_{2}$ retrieval algorithm for the thermal infrared spectra of the Greenhouse Gases Observing Satellite: Potential of retrieving $\mathrm{CO}_{2}$ vertical profile from high-resolution FTS sensor, J. Geophys. Res., 114, D17305, doi:10.1029/2008JD011500, 2009.

Schneising, O., Buchwitz, M., Burrows, J. P., Bovensmann, H., Reuter, M., Notholt, J., Macatangay, R., and Warneke, T.: Three years of greenhouse gas column-averaged dry air mole fractions retrieved from satellite - Part 1: Carbon dioxide, Atmos. Chem. Phys., 8, 3827-3853, doi:10.5194/acp-8-3827-2008, 2008.

Sussmann, R., Stremme, W., Buchwitz, M., and de Beek, R.: Validation of ENVISAT/SCIAMACHY columnar methane by solar FTIR spectrometry at the Ground-Truthing Station Zugspitze, 
Atmos. Chem. Phys., 5, 2419-2429, doi:10.5194/acp-5-24192005, 2005.

Sussmann, R., Rettinger, M., and Borsdorff, T.: The new TCCONFTS site at Garmisch, Germany $\left(47^{\circ} \mathrm{N}, 11^{\circ} \mathrm{E}, 744 \mathrm{~m}\right.$ a.s.1.): Set up, first year of operation, and contribution to OCO and GOSAT validation, Geophysical Research Abstracts., 11, EGU20098780-2, 2009.

Toon, G. C., Farmer, C. B., Schaper, P. W., Lowes, L. L., and Norton, R. H.: Composition measurements of the 1989 Arctic winter stratosphere by airborne infrared solar absorption spectroscopy, J. Geophys. Res., 97, 7939-7961, doi:10.1029/91JD03114, 1992.

Tran, H. and Hartmann, J.-M.: An improved $\mathrm{O}_{2}$ A band absorption model and its consequences for retrievals of photon paths and surface pressures, J. Geophys. Res., 113, D18104, doi:10.1029/2008JD010011, 2008.

Tran, H., Boulet, C., and Hartmann, J.-M.: Line mixing and collision-induced absorption by oxygen in the $\mathrm{A}$ band: Laboratory measurement, model, and tools for atmospheric spectra computations, J. Geophys. Res., 111, D15210, doi:10.1029/2005JD006869, 2006.

Washenfelder, R. A., Toon, G. C., Blavier, J.-F., Yang, Z., Allen, N. T., Wennberg, P. O., Vay, S. A., Matross, D. M., and Daube, B. C.: Carbon dioxide column abundances at the Wisconsin Tall Tower site, J. Geophys. Res., 111, D22305, doi:10.1029/2006JD007154, 2006.

WMO: The state of greenhouse gases in the atmosphere using global observations through 2008, WMO Greenhouse Gas Bulletin, No. 5, 2009.
World Data Centre for Greenhouse Gases: "WMO Global Watch World Data Centre for Greenhouse Gases ", http://gaw.kishou. go.jp/wdcgg/, last access: June, 2011.

Wunch, D., Toon, G. C., Wennberg, P. O., Wofsy, S. C., Stephens, B. B., Fischer, M. L., Uchino, O., Abshire, J. B., Bernath, P., Biraud, S. C., Blavier, J.-F. L., Boone, C., Bowman, K. P., Browell, E. V., Campos, T., Connor, B. J., Daube, B. C., Deutscher, N. M., Diao, M., Elkins, J. W., Gerbig, C., Gottlieb, E., Griffith, D. W. T., Hurst, D. F., Jiménez, R., Keppel-Aleks, G., Kort, E. A., Macatangay, R., Machida, T., Matsueda, H., Moore, F., Morino, I., Park, S., Robinson, J., Roehl, C. M., Sawa, Y., Sherlock, V., Sweeney, C., Tanaka, T., and Zondlo, M. A.: Calibration of the Total Carbon Column Observing Network using aircraft profile data, Atmos. Meas. Tech., 3, 1351-1362, doi:10.5194/amt-31351-2010, 2010.

Wunch, D., Toon, G. C., Blavier, J.-F. L., Washenfelder, R. A., Notholt, J., Connor, B. J., Griffith, D. W. T., Sherlock, V., and Wennberg, P. O.: The Total Carbon Column Observing Network (TCCON), Philos. T. Roy. Soc. A., 369, 2087-2112, doi:10.1098/rsta.2010.0240, 2011.

Yoshida, Y., Ota, Y., Eguchi, N., Kikuchi, N., Nobuta, K., Tran, H., Morino, I., and Yokota, T.: Retrieval algorithm for $\mathrm{CO}_{2}$ and $\mathrm{CH}_{4}$ column abundances from short-wavelength infrared spectral observations by the Greenhouse gases observing satellite, Atmos. Meas. Tech., 4, 717-734, doi:10.5194/amt-4-717-2011, 2011.

Yokota, T., Yoshida, Y., Eguchi, N., Ota, Y., Tanaka, T., Watanabe, H., and Maksyutov, S.: Global concentrations of $\mathrm{CO}_{2}$ and $\mathrm{CH}_{4}$ retrieved from GOSAT: First preliminary results, Scientific Online Letters on the Atmosphere (SOLA), 5, 160-163, doi:10.2151/sola.2009-041, 2009. 